\title{
総説と解説
}

\section{クラスターの化 学}

山内 薰* ·近藤 保**

* 東京大学教養学部基礎学科 目黒区駒場（干153）

** 東京大学理学部化学教室 文京区本鄉（干113）

（1986年 9 月 11 日受理）

Chemistry initiated by cluster beams

Kaoru Yamanouchi* and Tamotsu Kondow**

* Department of Pure and Applied Sciences, College of Arts and Sciences,

The University of Tokyo, Komaba, Meguro-ku, Tokyo 153, Japan.

** Department of Chemistry, Faculty of Science, The University of Tokyo,

Hongo, Bunkyo-ku, Tokyo 113, Japan.

(Received September 11, 1986)

\section{1. 序}

原子・分子は希薄気体中では孤立した状態にある・気 体の密度が増加すると拉互いに衝突する回数が増え 会 合体（クラスター）が形成されるようになる，さらに密 度が增えると粒子間の相互作用のためついには凝縮を起 こし，液体や固体となる.この凝縮過程に現われるクラ スターには，どのようにその構成原子・分子の性質が反 映されるのだろらか，凝縮相としての性質は構成粒子の 数“ $\mathrm{n} ”$ がどの程度になると現われるのだろらか. クラ スターには，原子・分子にも凝縮相にもない特色ある性 質があるのだろうか.

ひとくちにクラスターといってもその nの大ささによ って性質は異なるであろう. $\mathrm{n}<10$ の領域では，とりら る安定な幾何学的構造の数はそれ程大きくはないので, クラスターは準分子としてとりあつからことができる.

一方, $10^{1}<\mathrm{n}<10^{2}$ の領域では, エネルギーの比較的近 い多くの準安定構造が存在し，クラスターは分子でも固 体でもない新しい物質系を形成すると考えられる，これ ら $\mathrm{n}<100$ の領域のクラスターについての研究は，ノズ ル分子線技術の発展とあいまって，ここ数年急速に進展
してきた。

本総説 では， $\mathrm{n}<100$ のクラスターについて，その性 質がnによってどのように変化するのかという点に着目 し，ノズル分子線を用いたクラスターについての最近の 研究を紹介する．また，クラスターはその構成粒子間の 結合様式によってその生成法や特性が異なるので，以下 の章では，金属原子クラスター(第 2 章)，共有結合クラ スター(第 3 章)，分子クラスター（第 4 章）に分類して 述べる. 現在発展中のこの分野の全体にわたるさらに詳 しい内容については, 現在発行されている優れた総説110)や国際会議のプロシーディング11-13) を参照されたい.

\section{2. 金属原子クラスター}

\section{1 アルカリ金属クラスター}

\section{1 .1 生成法}

$\mathrm{Na}$ などのアルカリ金属は低温でも蒸気圧が高いので, 炉の内部に金属試料を置いて加熱することによって金属 クラスターを生成するのに充分な蒸気圧にすることがで きる. それを真空中に噴出させることによってクラスタ 一を生成する ${ }^{14,15)}$ ，近年では，10気圧程度までに加圧し た希ガスなどをキャリヤーガスとして用いることによ 


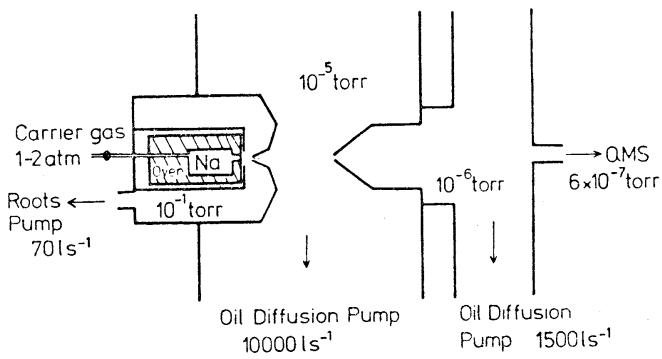

Fig. 1 Schematic of the seeded-beam apparatus [Ref. 16].

(Kappes et al. : Chem. Phys. Lett. 91, 413 (1982), Fig. 1)

り，さらに効率よくクラスターを生成させる方法も用い られるようになっている15-17). Fig. 1 に, Schumacher

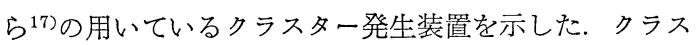
ターの生成効率をあげ, 生成したクラスターが他の気体 との衝突によって解離することを防ぐため, 差動排気を 用いて真空度を良くすることが必要となる，そのため排 気系が大規模になる，また，生成するクラスターのサイ ズ分布は，よどみ圧，ノズル穴径，金属の蒸気圧（炉の 温度）によって変化させることがでさる，以下では，主 に $\mathrm{n} \geqq 3$ 以上のクラスターの研究について述べる. アル カリ金属二量体 $(\mathrm{n}=2)$ については加藤の総説 ${ }^{18)}$ を参照 されたい.

\section{1 .2 イオン化ポテンシャル}

イオン化ポテンシャルは金属クラスターの電子状態に 関連する比較的得やすい情報のひとつである. Na クラ スター $\left(\mathrm{Na}_{n}\right)$ のイオン化ポテンシャルは, はじめ

[ev]

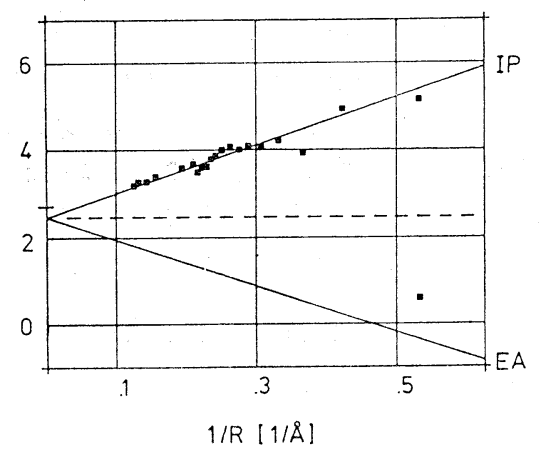

Fig. 2 Plots of experimentally determined photoionization potentials for sodium clusters against $1 / R . \quad R$ represents the radius of a sphere with the same volume as an n-atomic cluster [Ref. 17].

(Kappes et al.: J. Chem. Phys. 84, 1863 (1986), Fig. 4)

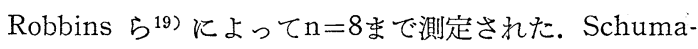
cher ら ${ }^{17)}$ のグループは測定を改良し，さらに $\mathrm{n}=65$ ま でのクラスターについてもその值を求めた，その結果を まとめたものが Fig. 2 である. この図では, クラスタ 一, $\mathrm{Na}_{\mathrm{n}}(\mathrm{n}=1-15,19,35,55,65)$ のイオン化ポテンシ ヤルをその有効半径 $R$ の逆数に対してプロットしてあ る.この球形金属モデル20)にもとづくと，仕事関数 $W(R)$ は古典的表現，

$$
W(R)=W_{\infty}+3 e^{2} / 8 R,
$$

で与えられる.この理論式 (1) を図中に直線で示す. n が20より小さな領域ではいくぶんこの直線からはずれる 部分があるものの，この式は実測のイオン化ポテンシャ ルのサイズ依存性をかなり良く再現している．また，こ の直線の外挿值から， $W_{\infty} \cong 2.6 \mathrm{eV}$ となり, $\mathrm{Na}$ 金属の 仕事関数 $(2.7 \mathrm{eV})$ に近い值となる.

イオン化によってクラスターが分解することや緩和な ぞによる効果を見積るために，波長可変のレーザーを用 いてイオン化ポテンシャルのサイズ依存性を精密に決定 する試みが報告されている. 最近 Brechignac と $\mathrm{Cahuzac}^{21,22)}$ はカリウムクラスター $\mathrm{K}_{\mathrm{n}}(\mathrm{n}=1 \sim 8)$ の

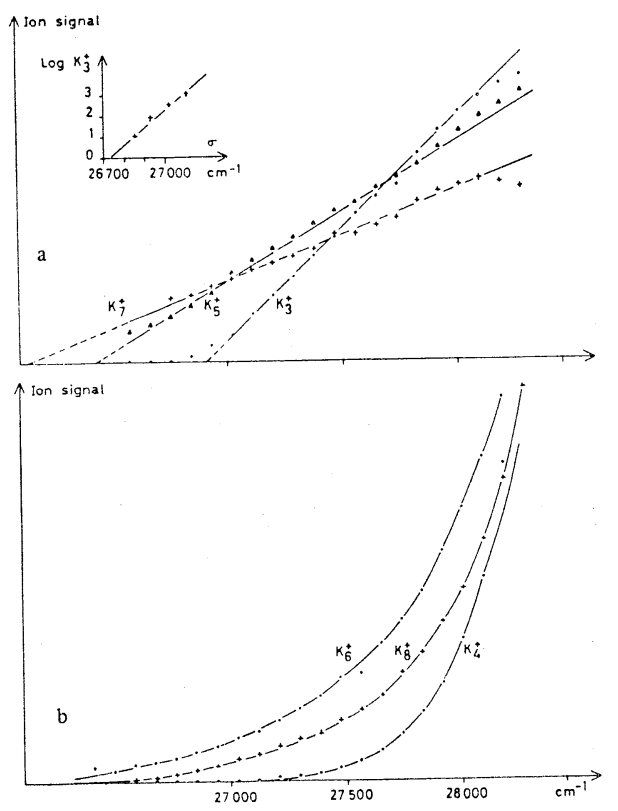

Fig. 3 Normalized one-photon ionization efficiency curves for the odd-numbered (a) and evennumbered (b) clusters. In the inset is shown a semi-logarithmic plot for the $\mathrm{K}_{3}{ }^{+}$ion signal in the pre-threshold region [Ref. 22].

(Brechignac and Cahuzac: Chem. Phys. Lett. 117, 365 (1985), Fig. 4) 


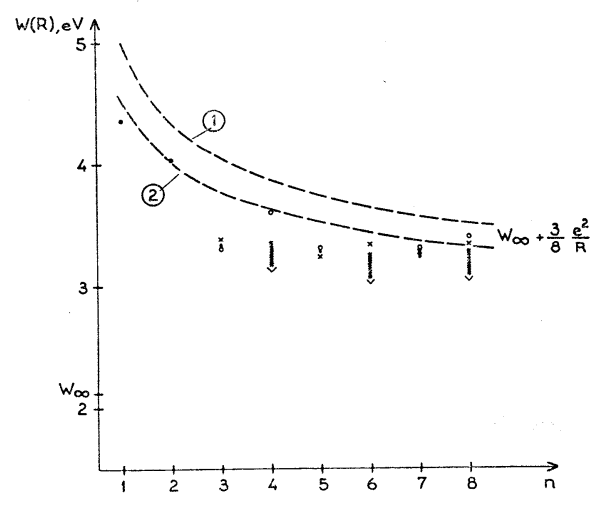

Fig. 4 Photoionization potentials for $\mathrm{K}_{\mathrm{n}}$ clusters. The dashed lines are calculated from the small metallic sphere picture: $W(R)=W_{\infty}+$ $(3 / 8) e^{2} / R$ where $W_{\infty}$ is the bulk work function, $e$ the electron charge and $R$ the cluster radius taken as $R_{\mathrm{n}}=r \cdot n^{(1 / 3)}$. For the curve (1) $r$ is deduced from the diatomic equilibrium distance; for the curve (2) the nearest neighbor distance in the bulk metal is considered [Ref. 21].

(Brechignac and Cahuzac: Laser Chem. 5, 321 (1986), Fig. 5)

光イオン化効率曲線をレーザーを用いて測定した．それ によると，nが偶であるか奇であるによってイオン化効 率曲線が全く異なる。すなわち，Fig. 3 亿示した様に， イオン化レーザーの波数の増加に伴い, $\mathrm{n}$ が奇のものは 1 次に依存するのに対して, $\mathrm{n}$ が偶のものは 2 次以上の 依存性を持つことがわかる，このことは，偶と奇ではイ オンと中性での平衝核配置の関係が異なるためであると している.この効率曲線を、イオンの信号がゼロになる 方向に外插することによりイオン化ポテンシャルが求め られる，ただし， nが偶の場合にはイオン化ポテンシヤ ルの值は正確には求をらず，その上限しかわからない。 得られた值を $1 \leqq \mathrm{n} \leqq 8$ についてプロットしたものが Fig. 4 である.ここで破線は理論式 (1) を示して招り， $W_{\infty}$ としてカリウム固体の仕事関数を用いている， $\mathrm{n} \leqq 8$ では式 (1) からのずれが大きい.イオン化のしきい值付 近でのこの様ならるまいを観測した例としては他に, $\mathrm{K}_{\mathrm{n}}$ クラスターについての Saundersら ${ }^{23)}$ の研究 $(3 \leqq \mathrm{n} \leqq 30)$, $\mathrm{Na}_{\mathrm{n}}$ クラスターについての Peterson ら ${ }^{24)}$ の研究 $(2 \leqq \mathrm{n} \leqq 8)$, Herrmann ら ${ }^{14)}$ の研究などがある.

\subsection{3 マジック数}

Knightら ${ }^{25)}$ は，Arをキャリヤーガスとする超音速自 由噴流中で作成した $\mathrm{Na}_{\mathrm{n}}(4 \leqq \mathrm{n} \leqq 100)$ の質量スペクト ルを測定し，強度が特に大きくなるサイズ n（マジック
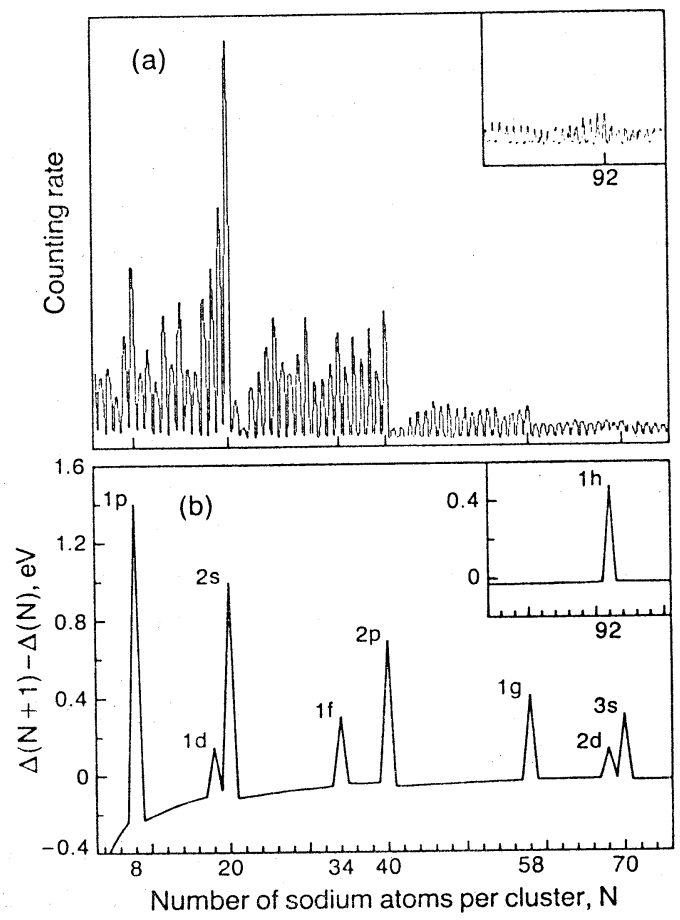

Fig. 5 (a) Mass spectrum of sodium clusters, $N$ $=4-75$. The full scale intensity in the main figure is approximately 20000 counts/s. Source conditions: $P(\mathrm{Ar})=750 \mathrm{kPa}, \quad P(\mathrm{Na})=24 \mathrm{kPa}$. The inset corresponds to $N=75-100$. (b) The calculated change in the electronic energy difference, $\Delta(N+1)-\Delta(N)$, vs $N$. The labels of the peaks correspond to the closed-shell orbitals [Ref. 25].

(Knight et al. : Phys. Rev. Lett. 52, 2141 (1984), Fig. 1)

数）が存在することを見出した. Fig. 5 に示すように， マジック数は, 8,20,40,58,92 である. Knight ら よび Chou ら ${ }^{26)}$ は, マジック数を持つ $\mathrm{Na}_{\mathrm{n}}$ クラスター が安定であることを殼模型を用いて説明した。すすおわら， 電子状態をその非局在化する $3 \mathrm{~s}$ 電子を用いて表わし， クラスター内部の有効ポテンシャルを球対称ポテンシャ ル

$$
u(r)=-u_{0} /\left(\exp \left(\frac{r-r_{0}}{\epsilon}\right)+1\right)
$$

で近似する.ここで $u_{0}$ はバルクでのフェルミェネルギ 一之仕事関数の和, $r_{0}$ は有効クラスター半径, $\in$ は球面 の内側と外側でのポテンシャルの変化を決めるパラメー ターである.それぞれのnについて全ェネルギー $E(\mathrm{n})$ を求めて， $\Delta E=E(\mathrm{n}+1)-E(\mathrm{n})$ をプロットしたものが 
Fig. 5(b)である.ちょうど閉殼構造をとるnの值でピー クが見出され，それはマジック数を医注完全に再現して いる.クラスターを検出するための光イオン化には, $\mathrm{Hg}$ 抢よび Xe ランプにフィルターを組み合わせたものを光 源として用いている.フィルターを交換することにより 光イオン化の波長をかえてもマジック数の值は変化しな かったので，実測の質量スペクトルの強度分布は中性の $\mathrm{Na}_{\mathrm{n}}$ クラスターの安定性を反映していると主張している. Knight ら ${ }^{27)}$ は同様の実験を $\mathrm{K}_{\mathrm{n}}$ クラスターについても 行ない,やはり, $\mathrm{n}=2,8,20,40$ にマジック数を見出し た.このことは，アルカリ金属クラスターの電子状態は 価電子の殼模型である程度推定できることを示してい る.このような比較的単純な殼模型がスピン配置を含め た電子状態の計算にどの程度有用であるかはこれからの 問題である. アルカリ金属クラスターのマジック数の理 論的とりあつかいについては，石井らの最近の報告 ${ }^{28,29}$ を参照されたい。

\section{1 .4 電子状態}

$\mathrm{K}_{\mathrm{n}}, \mathrm{Na}_{\mathrm{n}}$ クラスターについては，最近，電場による偏 向の実験 ${ }^{30)}$ が行なわれ，クラスターサイズによって，そ の構成原子 1 個あたりの平均分極率がいかに変化するか が調べられている。これによると，閉殼構造をとるnの 付近で分極率が極小となることが見出されている。また， 磁場によるStern-Gerlach タイプの偏向実験 31,32 Vよる と, $\mathrm{n}$ が偶の場合には不均一磁場によって偏向しないが, $\mathrm{n}$ が奇となると偏向が観測される。これは，nが偶のと きは全電子スピンの和はゼ口であるが， $\mathrm{n} か ゙$ 奇となると， $1 つ の$ 電子が電子対をつくることができずに常磁性とな

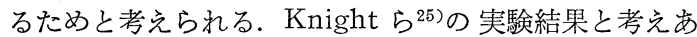
わせると，この電子対が $1,4,10$ となるとき特に安定な 閉款構造となる. Brechignac と Cahuzac ${ }^{21,22)}$ は $\mathrm{K}_{2}$ の ような二量体が単位となってクラスターが形成されると してイオン化のしきい值付近での奇と偶のクラスターの ふるまいを説明している. しかしこれは殼構造の考光方 とは必ずしも一致するものではない，低次元系に見られ るパイエルス不安定性などが構造を支配して和り, 殸模 型が成立しなくなっている可能性を示唆している.

\section{2 遷移金属クラスター}

\subsection{1 生成法}

Feなどの遷移金属は通常融点も高く，アルカリ金属ク ラスターの生成に用いられたような炉を用いてはクラス ターを作るのに十分な蒸気圧を得にくい。このような高 融点物質のクラスタービームを可能としたのは, Smalley ら和よび Bondybey らのグループが発展させ たレーザー蒸発法 ${ }^{33},{ }^{34)}$ である。この方法では，Fig. 6 に

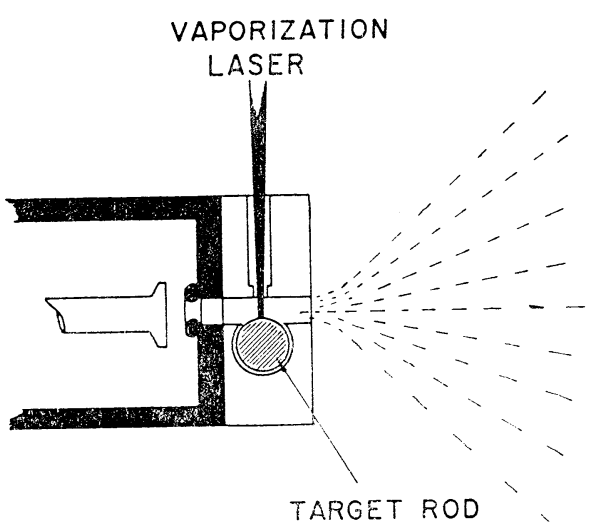

Fig. 6 Schematic cross section of a pulsed metal cluster nozzle. Metal vaporization is accomplished by a Q-switched green second harmonic laser beam from a Nd: YAG laser focused to a $0.15-\mathrm{cm}$ diameter spot on a copper rod. This rod is rotated and translated continuously by a screw drive mechanism so as to avoid drilling a deep hole with the laser. The ejected copper plasma produced by the laser is entrained in helium flowing at near sonic velocity in a $0.2-\mathrm{cm}$ diameter channel $0.4-\mathrm{cm}$ upstream from the point of free expansion into a vacuum. Gas feed to this vaporization channel is through a fast solenoid-actuated pulsed valve [R.ef. 35]. (Powers et al.: J. Phys. Chem. 86, 2556 (1982), Fig. 1)

示したよらに試料となる金属のロッドをノズルの面前に 置きレーザー光を空からロッドに集光して金属を蒸発 させることによりプラズマ状態を生成させる，同時に， 上流のパルスバルブより He などの希ガスを噴出させ， 金属蒸気とともにノズルから真空中に自由膨張させる過 程でクラスターを生成させる，通常，ロッドを回転しな がらスライドし，常に新しい面から蒸発できるようにす る.レーザーによる金属表面のスパッタリングによりプ ラズマ状態が生成されることは， $\mathrm{Pt}, \mathrm{Al}, \mathrm{W}, \mathrm{Be}$ など

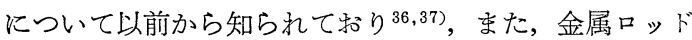
を回転しながらレーザーを照射する方法についても報告 がある ${ }^{38}$. このレーザー蒸発法は，1980年代になると， Smalley ら, Bondybeyら, Kaldor ら, Riley らのグル 一プなどで金属をはじめとする様々なクラスターの生成 に用いられるようになった。この方法によれば，パルス 状のビームを作ることが可能であるし， 3 章で述べるよ うに, 共有結合クラスターの生成にも有効である。また， Fig. 7 に示すように，ノズルの下流に反応管を付けるこ とによってクラスターと他の分子との反応や吸着といっ 


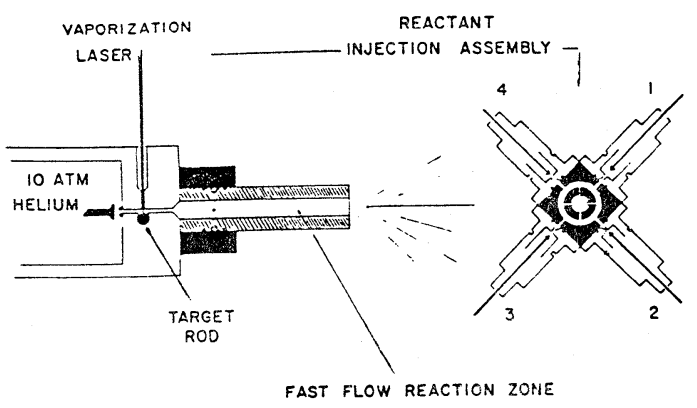

Fig. 7 Schematic of a gas-phase metal cluster reaction device. Metal clusters are generated by focusing a $30-40 \mathrm{~mJ}, 6$ ns-duration laser beam (Nd: YAG 2 nd hamonic) to a $0.1 \mathrm{~cm}$ diam. spot on a pure target rod of the desired metal. Helium carrier gas is pulsed over this rod such that the density above the rod at the time of vaporization is 1-2 atom. Metal clusters in the $2-20$ atom size range are formed and thermalized in the near-sonic flow of this helium carrier as it passes down a 0.2 $\mathrm{cm}$-diam, 1.8-cm-long thermalization channel (shown here in cross section). This heliummetal cluster mixture then flows through a $1-\mathrm{cm}$-diam $10-\mathrm{cm}$-long reaction tube into which reactants are injected through four needles. As seen in the end view, these four needles are fed from an annular ring which, in turn, receives reactant gas from any of four independent pulsed solenoid valves [Ref. 39]

(Geusic et al.: Rev. Sci. Instrum. 56, 2123 (1985), Fig. 1)

た過程を調べることができる ${ }^{39)}$.

\subsection{2 イオン化ポテンシャル}

ここでは遷移金属クラスターの代表例として $\mathrm{Fe}_{\mathrm{n}}$ クラ スターについて述べる. Rohlfing ${ }^{40,41)}$ はd YAGレ ーザーの 2 倍波 $(532 \mathrm{~nm})$ を用いたレーザー蒸発法によ って $\mathrm{Fe}_{\mathrm{n}}$ クラスターを生成させ，それを別の波長可変の レーザー光を用いて光イオン化して検出している. $\mathrm{n}=$ 2〜25 の範囲のイオン化 ポテンシャルを求めたところ Fig. 8 に示したよらなサイズ依存性が見出された. n が大きくなるにつれてイオン化ポテンシャルが減少し， バルクの仕事関数に近ずくという大まかな傾向が見られ る. さらに，n〜10 で極小となり $\mathrm{n} \sim 16$ で極大となるよ らな比較的ゆるやかな変動が見出される， $\mathrm{Fe}_{\mathrm{n}}$ の電子状 態は単純ではなく，この変動の定性的な説明はまだ与え られていない，電子状態が複雑であるひとつの理由は電 子スピンの配置とスピンースピン相互作用を考慮しなけ

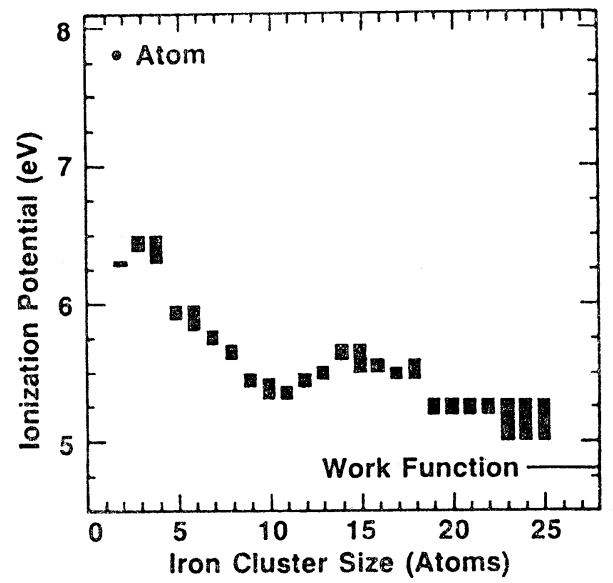

Fig. 8 The ionization potentials of iron clusters determined from the photoionization spectra plotted vs. cluster size. The work function of bulk iron is also indicated [Ref. 41]. (Rohlfing et al. : J. Chem. Phys. 81, 3846 (1984), Fig. 3)

ればならないという点である41).

金属クラスター，特に遷移金属クラスターの電子状態 を実験的に調べる最も有力な手段の一つは帯磁率や磁気 共鳴（たとえばレーザー磁気共鳴）などの測定である.

現在ではサイズのそろったクラスタービームを作ること は困難であるので, 特定の $\mathrm{n}$ のクラスターの検出方法を 工夫する必要がある. 理論的には比較的 $\mathrm{n}$ のさなクラ スターの電子状態は電子移動相互作用や電子相関によっ て特徵づけられていると思われる。菅野らの Hubbard モデル42)は小さなクラスターの電子構造の特徴をとらえ ていると考えられ，電子状態が Jahn-Teller ひずみなど を通じてクラスターの構造と関連することを説明する.

クラスターのサイズが大きくなっても, 電子状態の特徴 を予想する基本的な考方方の枠組は変らないように思わ れるが，集団的な内部運動との関連など大きなクラスタ 一特有の問題が生じて来るであろら.

\subsection{3 $\mathrm{Fe}_{\mathrm{n}}$ クラスターと $\mathrm{H}_{2}$ の反応}

$\mathrm{Fe}_{\mathrm{n}}$ クラスターについては, $\mathrm{H}_{2}$ との反応性に和いて も，イオン化ポテンシャルに見られたのと類似したサイ ズ依存性のあることが Richtsmeier ら ${ }^{43}$ によって確認 されている. 彼らは Fig. 7 に示したものと同じタイプ の反応管のついたノズルを用いて， $\mathrm{Fe}_{\mathbf{n}}$ と $\mathrm{H}_{2}$ の反応過 程の研究を行なった. レーザー蒸発には $\mathrm{XeCl}$ エキシマ ーレーザーを, また, 光イオン化には ArF エキシマー レーザーを用いている，得られた質量スペクトルの一例 をFig. 9 に示した. $\mathrm{Fe}_{11} \sim \mathrm{F}_{26}$ の範囲については，反応 


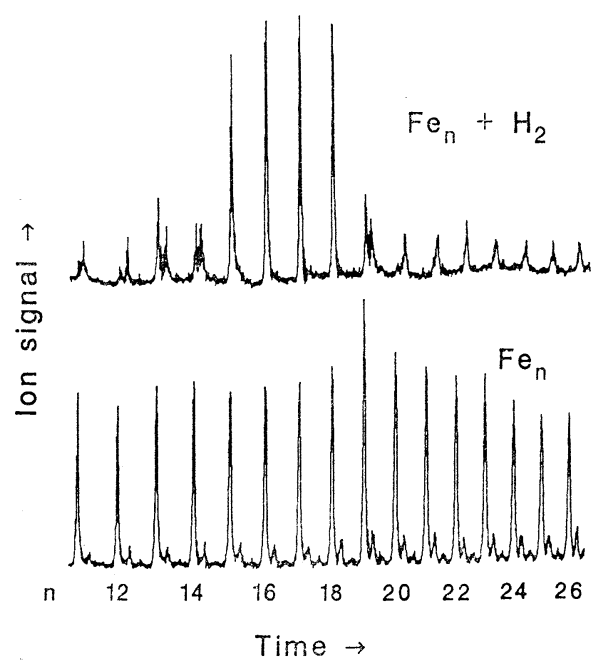

Fig. 9 A portion of the cluster time-of-flight mass spectrum showing $\mathrm{Fe}_{11}$ to $\mathrm{Fe}_{26}$ species. The lower panel is the bare cluster signal (no regent gas). Satellite peaks are impurities, mostly cluster oxides and dioxides. For the upper panel, $7 \mathrm{sccm}$ (std. $\mathrm{cm}^{3} \mathrm{~min}^{-1}$ ) of $\mathrm{He}$ was added to the regent line. Note the small extent of reaction shown by $\mathrm{Fe}_{15}$ through $\mathrm{Fe}_{18}$, and the varying degrees of reaction for the other clusters [Ref. 43].

(Richtsmeier et al.: J. Chem. Phys. 82, 3659 (1985), Fig. 2)

領域に $\mathrm{H}_{2}$ を加えると，それまでなめらかであった $\mathrm{n} に$ 関する分布が顕著に変化し, $\mathrm{Fe}_{\mathrm{n}}$ が減少して $\mathrm{Fe}_{\mathrm{n}} \mathrm{H}_{\mathrm{m}}$ 型の 水素化物のピークに移行する. また, $\mathrm{Fe}_{15} \sim \mathrm{Fe}_{18}$ では他 のサイズのクラスターに比較してその反応性が低い、こ の $\mathrm{Fe}_{\mathrm{n}}$ の減少を $\mathrm{H}_{2}$ の濃度を変化させて測定し， $\mathrm{Fe}_{\mathrm{n}} に$ $\mathrm{H}_{2}$ が 1 分子だけ反応するときの速度定数 $k(\mathrm{n})$ を求める

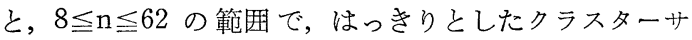
イズ依存性がある(Fig. 10).すなわち， $k(\mathrm{n})$ は n〜1 で極大， $\mathrm{n} \sim 17$ で極小となったのち $\mathrm{n} \sim 23$ からほぼ一 定となる.

Whetten ら ${ }^{44}$ は同様の実験を $\mathrm{Fe}_{\mathrm{n}}$ クラスターについ て行ない，イオン化ポテンシャルのクラスターサイズ依 存性と比較した. その結果, イオン化ポテンシャルの極 大と極小は，反応速度の極小と極大と良く対応すること がわかった. これは, Fig. 8 と Fig. 10 を比較すること によってもわかる. このことから， $\mathrm{Fe}_{\mathrm{n}}$ クラスターから $\mathrm{H}_{2}$ への電子移行が反応に寄与することが示唆された.

一方, $\mathrm{H}_{2}$ 分子が $\mathrm{Fe}_{\mathrm{n}}$ クラスターに解離吸着するのか どうかについても調べられている. Liuら ${ }^{45)} は, \mathrm{H}_{2}$ が吸 着した $\mathrm{Fe}_{\mathrm{n}}$ クラスターを光解離させることによって，

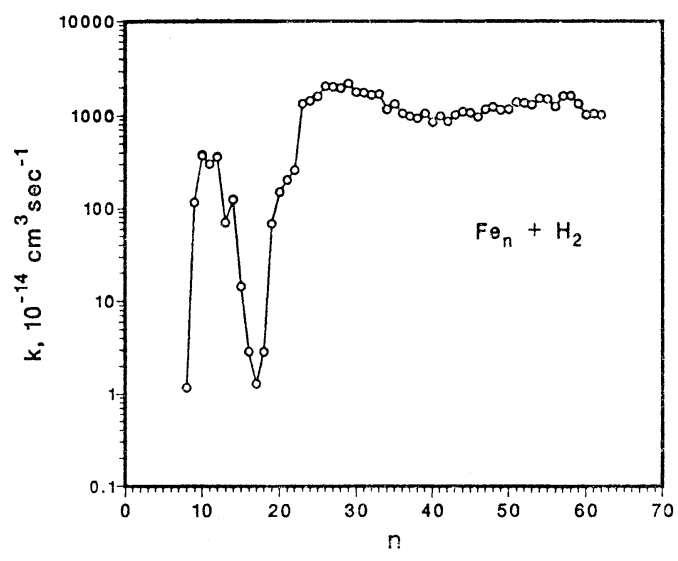

Fig. 10 Cluster size dependence of the rate constants for reaction with $\mathrm{H}_{2}$ [Ref. 43]. (Richtsmeier et al.: J. Chem. Phys. 82, 3659 (1985), Fig. 4)

$\mathrm{H}_{2}$ の吸着が解離吸着であることを示した。すなわち， ArFレーザーの 1 光子ごとに拉よそ 5 個の $\mathrm{H}_{2}$ 分子が解 離されることがわかり，1個あたりの解離エネルギーが 約 $1.3 \mathrm{eV}$ と求められた。 これは $\mathrm{Fe}$ 金属表面上での $\mathrm{H}_{2}$ の解離エネルギー $(0.8 \sim 1.1 \mathrm{eV})$ より少し高いもの の, $\mathrm{Fe}-\mathrm{H}$ の強い結合 $(\sim 2.8 \mathrm{eV})$ が形成される解離吸 着であることを示している.

また，反応領域での $\mathrm{H}_{2}$ の圧力を変化させると生成す る水素化物 $\left(\mathrm{Fe}_{\mathrm{n}} \mathrm{H}_{\mathrm{m}}\right)$ に含まれる水素濃度が変化するこ とが見出された ${ }^{46)} . \mathrm{H}_{2}$ の圧力が比較的低い 100 Torr 以 下の場合には，検出される $\mathrm{Fe}_{\mathrm{n}} \mathrm{H}_{\mathrm{m}}$ の $\mathrm{m}$ の值は特定の $\mathrm{n}$ については核ぼ一定で，圧力の変動に敏感でないことが 示された. この“飽和水素化合物”の $\mathrm{n}$ とをて゚ロット したものが Fig. 11 である。この図から明らかなように， $\mathrm{n} \leqq 30$ では $\mathrm{m} / \mathrm{n} \sim 1$ であるが， $\mathrm{n} \geqq 30$ では $\mathrm{m} / \mathrm{n}<1$ と なる傾向にある.この $\mathrm{n}$ 学の関係は, 球を仮定した $\mathrm{Fe}$ クラスターの表面の第一層の $\mathrm{Fe}$ 原子にのみ $\mathrm{H}_{2}$ が吸着 するモデルによって医滦現できることがわかった。一 方で, $\mathrm{Fe}_{14} \mathrm{H}_{18}, \mathrm{Fe}_{22} \mathrm{H}_{19}$ のように $\mathrm{m} \sim \mathrm{n}$ が成り立たず, その $\mathrm{n}$ の前後で $\mathrm{m}$ の值が大きく変化するものもめり, $\mathrm{n}$ $=14,22$ はマジック数と考光られる. $\mathrm{H}_{2}$ の圧力をさら に上げていくと永が増加しはじめる。これは表面がすで にH原子で扣扣われている上にさらに $\mathrm{H}_{2}$ が吸着した “物理吸着”的なものではないかと予想されている.

$\mathrm{Fe}_{\mathrm{n}}, \mathrm{Co}_{\mathrm{n}}, \mathrm{Ni}_{\mathrm{n}}, \mathrm{Cu}_{\mathrm{n}}, \mathrm{Nb}_{\mathrm{n}}$ などの遷移金属クラスター と $\mathrm{H}_{2}, \mathrm{~N}_{2}, \mathrm{CO}$ といった分子との反応についても研究が なされている47,48). $\mathrm{Fe}_{\mathrm{n}}, \mathrm{Co}_{\mathrm{n}}, \mathrm{Nb}_{\mathrm{n}}$ クラスターでは, $\mathrm{H}_{2}$ との反応に特いて顕著なサイズ依存性が見出されて特 


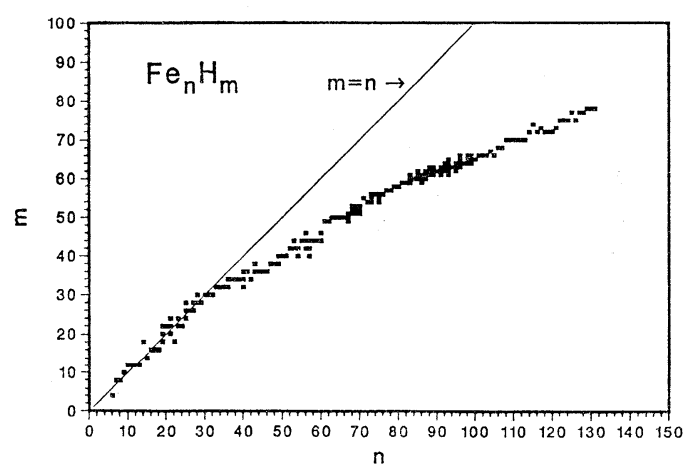

Fig. 11 Composition of the cluster hydrides $\mathrm{Fe}_{n} \mathrm{H}_{m}$. For $\mathrm{n}<60$, the plotted symbols correspond to the hydrides that have appreciable intensity in the mass spectra. For $60<\mathrm{n}<$ 100 , the center of each symbol corresponds to the center of the observed mass peak (individual hydrides are not resolved above $\mathrm{n}=60$ ) and the height gives the range of $\mathrm{m}$ values that contribute to the peak. Above $\mathrm{n}=100$ only the peak center is indicated [Ref. 46].

(Parks et al.: J. Chem. Phys. 82, 5470 (1985), Fig. 1)

り， $\mathrm{Ni}_{\mathrm{n}}$ クラスターでは反応はするものの明確なサイズ 依存性はない，一方， $\mathrm{Cu}_{\mathrm{n}}$ クラスターは $\mathrm{H}_{2}$ とはほとん ぞ反応しない，このことは， $\mathrm{H}_{2}$ 分子の解離吸着が開い たd軌道を持つ遷移金属に特有であるということに対応 する. $\mathrm{N}_{2}$ は $\mathrm{H}_{2}$ と類似した反応性を示すが， $\mathrm{CO}$ はい ずれの金属クラスターとも反応するもののサイズ依存性 は見出されなかった．CO が分子の形で吸着しているの か，それとも解離吸着しているのかについてはまだ明ら かではない。

\subsection{4 $\mathrm{Fe}_{\mathrm{n}}$ クラスターに関するその他の研究}

Brucat ら ${ }^{49}$ はレーザー蒸発法によって生成した $\mathrm{Fe}_{\mathrm{n}}$ クラスターを $\mathrm{ArF}$ エキシマーレーザーでイオン化した のち TOF 法によって特定の $\mathrm{Fe}_{\mathrm{n}}{ }^{+}(\mathrm{n}=2 \sim 8)$ クラスタ 一を分離した. これを $\mathrm{Nd}$ YAGレーザー励起の色素レ 一ザーによって解離させ, そのフラグメントを再び TOF 法によって検出した. その結果， 1 光子に上る光解離で は，いずれも 1 個の $\mathrm{Fe}$ 原子が解離することが見出され た.このことは, $\mathrm{Ni}_{\mathbf{n}}, \mathrm{Nb}_{\mathrm{n}}$ クラスターについても確か められた。 また，中性の $\mathrm{Fe}_{2}$ と $\mathrm{Fe}_{3}$ の解離エネルギー がそれぞれ，0.83〜1.32 eV, $1.17 \sim 2.18 \mathrm{eV}$ の範囲にあ ることがわかった．このような，質量分離された金属ク ラスターイオンの光解離実験は, 中性の金属クラスター の結合エネルギーを与光る有効な手法と考光られる。
た，金属クラスターの解離過程には数多くの電子励起状 態のポテンシャルェネルギー面が関与すると考兄られ， 普通の分子の単分子反応過程とは異なった理論的取扱い が必要であることが指摘された。

一方, $\mathrm{Cox}{ }^{50)}$ 性, $\mathrm{Fe}_{\mathrm{n}}(\mathrm{n}=2 \sim 17)$ クラスターについ て Stern-Gerlach タイプの磁場偏向実験を行ない, クラ スターの電子状態関する知見を得た. 彼らは、レーザ 一蒸発法によって生成した $\mathrm{Fe}_{\mathrm{n}}$ クラスターを不均一磁場 で偏向させたのち ArF エキシマーレーザーによってイ オン化し，そのイオンをTOF 法によって質量分析した. その結果, $\mathrm{Fe}_{2}, \mathrm{Fe}_{3}$ クラスターの磁気モーメントはそれ ぞれ 6.5(1) $\mu_{0}, 8.1(1) \mu_{0}$ であり, $\mathrm{n} \geqq 3$ についても, クラスターサイズにほぼ比例して磁気モーメントが増加 することがわかった．Fe 原子1個あたりにな招すと， $\mathrm{Fe}$ 金属での值 $2.2 \mu_{0}$ よりもいくらか大きい程度である ので, これら $\mathrm{Fe}_{\mathrm{n}}$ クラスターは磁気的性質だけから見れ ば，強磁性体である $\mathrm{Fe}$ 金属の前駆体と考兄られる。 た, $\mathrm{Fe}_{\mathrm{n}}$ クラスターについては, 理論的にもスピンの偏 極を考慮した電子状態拉よびバンド構造の計算が行な われて呿り ${ }^{51-53)}$ ，磁気モーメントについては，Coxらの 実験值と矛盾のない結果が得られている.

\subsection{5 その他の金属クラスターの研究}

$\mathrm{Sb}_{\mathrm{n}}, \mathrm{Bi}_{\mathrm{n}}, \mathrm{Pb}_{\mathrm{n}}$ などのクラスターの生成については, アルカリ金属と同様の高温炉を用いる方法が利用されて いる ${ }^{54,55)}$. 電子衝撃によるイオン化の後に質量スペクト ルを測定したところ， $\mathrm{Sb}_{\mathrm{n}}$ ではnが4の倍数ごとに強度 の大きなピークが観測された。これは， $\mathrm{Sb}_{4}$ が単位とな ってクラスターが形成されることを示唆している。 また， $\mathrm{Ag}_{\mathrm{n}}$ クラスターについては, 電子回折法 ${ }^{56}$ とよってその 構造に関する知見が得られている. 金属状態での fcc 構 造を仮定すると，nが小さいクラスターほど fcc 構造か らのずれが大きいことが見出された.

\section{3. 共有結合クラスター}

共有結合性を持つ様々なクラスターについてもレーザ 一蒸発法を利用した研究が行われはじめた。この章では, 特に $\mathrm{Si}_{\mathrm{n}}, \mathrm{Ge}_{\mathrm{n}}, \mathrm{C}_{\mathrm{n}}$ についての研究を紹介する.

\section{$3.1 \mathrm{Si}, \mathrm{Ge}$ クラスター}

Bloomfield ら ${ }^{577}$ は, Si のロッドをレーザー蒸発させ, 生成した $\mathrm{Si}_{\mathrm{n}}$ クラスターを $\mathrm{ArF}$ エキシマーレーザーで イオン化した，さらにそのイオンを質量分析して注目す るサイズのイオンクラスターのみを選別し, Nd YAGレ 一ザー光を用いて光解離を起こさせた，そして，光解離 レーザーの強度に対するフラグメントイオンの強度変化 から，特定の $\mathrm{n}$ を持つイオンクラスターの光解離がどの 


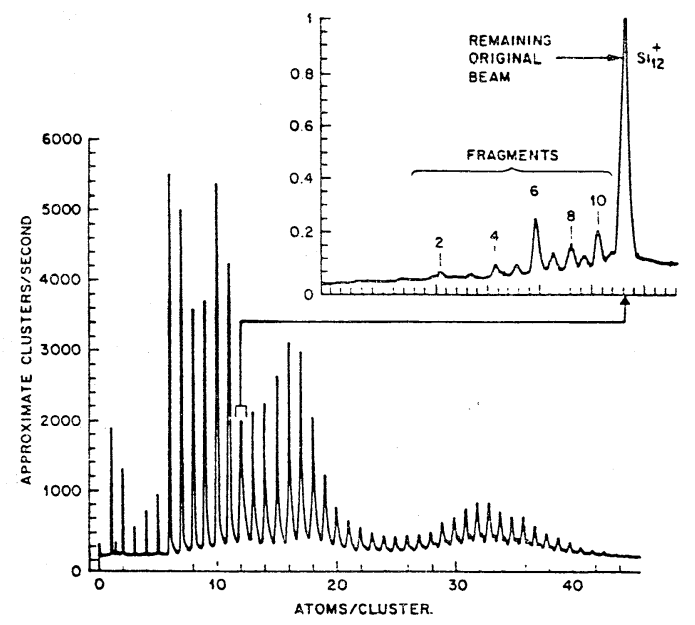

Fig. 12 A spectrum of small to medium cluster ions. An example of the preselection of cluster size is shown on the upper right where a single ion mass, $\mathrm{Si}_{12}^{+}$, is isolated and fragmented with $266-\mathrm{nm}$ radiation to produce the fragmentation spectrum shown on the upper right [Ref. 57].

(Bloomfield et al.: Phys. Rev. Lett. 54, 2246 (1985), Fig. 2)

ように進行するのかを調べた. 典型的な質量スペクトル と $\mathrm{Si}_{12}^{+}$の光解離スペクトルを Fig. 12 に示す. この実 験から，a） $\mathrm{n} \leqq 12$ のイオンクラスターの 光解離では, 正電荷はサイズの大きい方のクラスターに残る傾向にあ る, b) $\mathrm{n}=7$ ～11 の場合には特に $\mathrm{Si}_{6}{ }^{+}$の生成が支配的 である，c) $\mathrm{Si}_{\mathrm{n}}{ }^{+}$の光解離の断面積は, 特に $\mathrm{n}=4,6,10$ で極小となる，ということが明らかにされた. $\mathrm{Si}_{10}$ はア ダマンタン型を，また， $\mathrm{Si}_{6}$ も対称性の高い形をしてお り, これらの構造が特に安定である可能性が指摘された. $\mathrm{Si}_{\mathrm{n}}$ クラスターの構造については, Phillips ${ }^{58)}$ が幾何学 的モデルを用いて考察している他, いくつかの理論計 算 59,60$)$ がある.

上記のように $\mathrm{Si}_{\mathbf{n}}$ クラスターの光解離は “蒸発的” で なく“開裂的”に起こると考えられる.この結果は, Heathら ${ }^{61)}$ によっても確認されている. HeathらはArF レーザーによる多光子イオン化の結果得られた $\mathrm{Si}_{\mathrm{n}}, \mathrm{Ge}_{\mathrm{n}}$

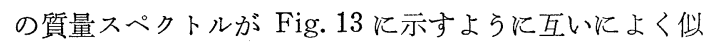
ていることを見出した. このスペクトルは， $\mathrm{n}=6$ ～11の イオンが，より $\mathrm{n}$ のきいクラスターの開裂の結果生成 することを示している. また， $\mathrm{n}=6$ ～11 の $\mathrm{Sin}_{\mathrm{n}}, \mathrm{Ge}_{\mathrm{n}}$ ク ラスターを Nd YAG レーザーの 2 倍波を用いて 2 光子 励起するか, あるいは 3 倍波を用いて 1 光子励起し, 時 間拈くれを和いてイオン化した. その結果，クラスター
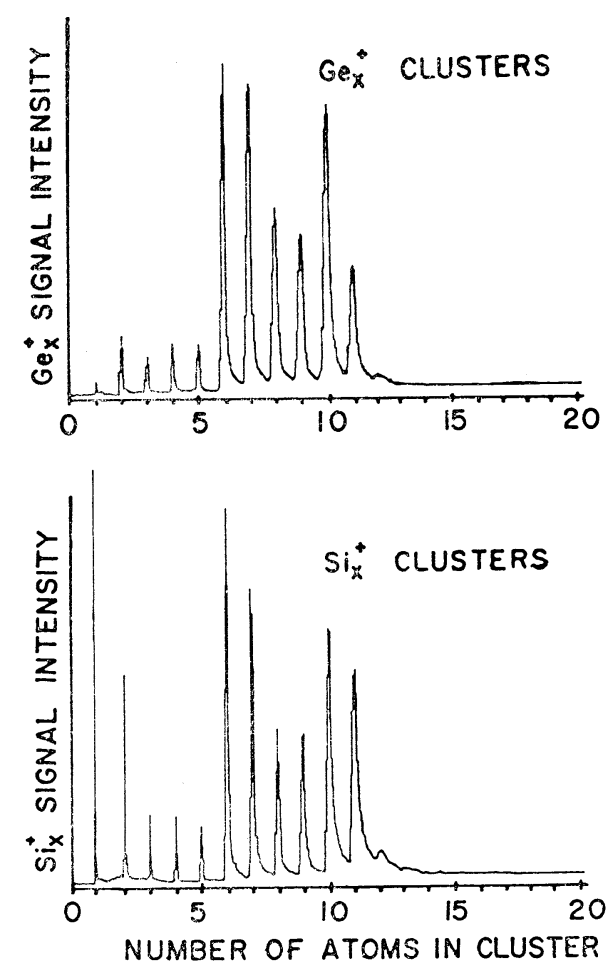

Fig. 13 Time-of-flight mass spectrum of germanium and silicon clusters. The clusters were ionized with a moderate fluence $\left(0.5 \mathrm{~mJ} / \mathrm{cm}^{2}\right)$ ArF excimer laser (6.4 eV). All cluster peaks shown are results of multiphoton ionization. The right-handed tails on the peaks for clusters containing 6-11 atom indicate that fragmentation from higher masses contributes to these channels. The instrument is optimized to observe clusters in the size range 6-20 [Ref. 61].

(Heath et al.: J. Chem. Phys. 83, 5520 (1985), Fig. 2)

が $100 \mathrm{~ns}$ 程の長い寿命を持つ励起状態に励起されるこ とがわかった.この長寿命励起状態の存在は, クラスタ 一に拈けるバンドギャップの存在を示唆している.

Siの比較的大さなクラスター $(\mathrm{n} \geq 100)$ については, 槽谷と仁科 ${ }^{62)}$, 抢よび Brus $^{63)}$ の報告がある.

\section{$3.2 \mathrm{C}_{\mathrm{n}}$ クラスター}

$\mathrm{C}_{\mathrm{n}}$ クラスターについても光イオン化に伴って解離が 起こることが見出されている．ただし，解離の特徽は $\mathrm{Si}_{\mathrm{n}}$ や $\mathrm{Ge}_{\mathrm{n}}$ とは少し異なっている. Rohlfing ら ${ }^{64)}$ ラファイトロッドをレーザー蒸発することによって, $\mathrm{n}=2 \sim 190$ の $\mathrm{C}_{\mathrm{n}}$ クラスターを観測した. 光イオン化に $\mathrm{KrF}$ エキシマーレーザーを用いた場合には，nの比較的 
小さい $(\mathrm{n} \leqq 25)$ クラスターは 3 光子でイオン化する. レ ーザーのフルーエンスを増加させると解離が進行し, 質 量スペクトルは，泀とんど $\mathrm{n} \leqq 5$ のイオンクラスターの みとなる， $\mathrm{C}_{3}{ }^{+}$の強度が特に大さいことから，これがイ オン化のフラグメントとして特に安定であると推定され ている. 異なった波長の光でイオン化し, 得られた質量 スペクトルのレーザーフルーエンス依存性を調べたとこ ろ, $\mathrm{n}<12$ ではイオン化ポテンシャルが $10 \sim 12 \mathrm{eV}$ で あるのに，n>40 ではnが偶のクラスターのみが見出さ れ，そのイオン化ポテンシャルは $5 \mathrm{eV}$ 以下であること がわかった. このことは，nが大きい領域と小さい領域 ではクラスターの構造が基本的に異なることを示してい る. Rohlfing らによる $\mathrm{C}_{\mathrm{n}}$ クラスターの質量スペクトル を Fig. 14 に示す. nの小さい領域ではクラスターイオ
ンの強度が 4 個扣きに強くなるという周期性が現れるこ と，また， $\mathrm{KOH}$ で処理したグラファイトロッドを用い た実験から $\mathrm{K}_{\mathrm{n}} \mathrm{C}_{2 \mathrm{n}}$ の一連のピークが質量スペクトルに 見出されたことから，一C $\mathrm{C}$ - 一ような直線鎖のクラ スターではないかと推定されている.

この $\mathrm{C}_{\mathrm{n}}$ クラスターについて, $\mathrm{n}$ の大きい領域でクラ スターの構造を推測する手がかりを与える実験が Kroto ら 65 によって行なわれた. 彼らは, Fig. 15 に示すよう

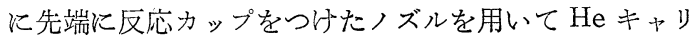
ヤーガスと $\mathrm{C}_{\mathrm{n}}$ クラスターとの接触時間を増加させたと ころ, $\mathrm{n}=60$ 以外のクラスターが汪とんど消滅すること を見出した (Fig. 16). $\mathrm{C}_{60}$ のピーク強度が他のnのも のよりも大きいことは, Fig. 14 の Rohlfing らのスペ クトルにも，また，Bloomfield (66)による $C_{n}$ クラスタ

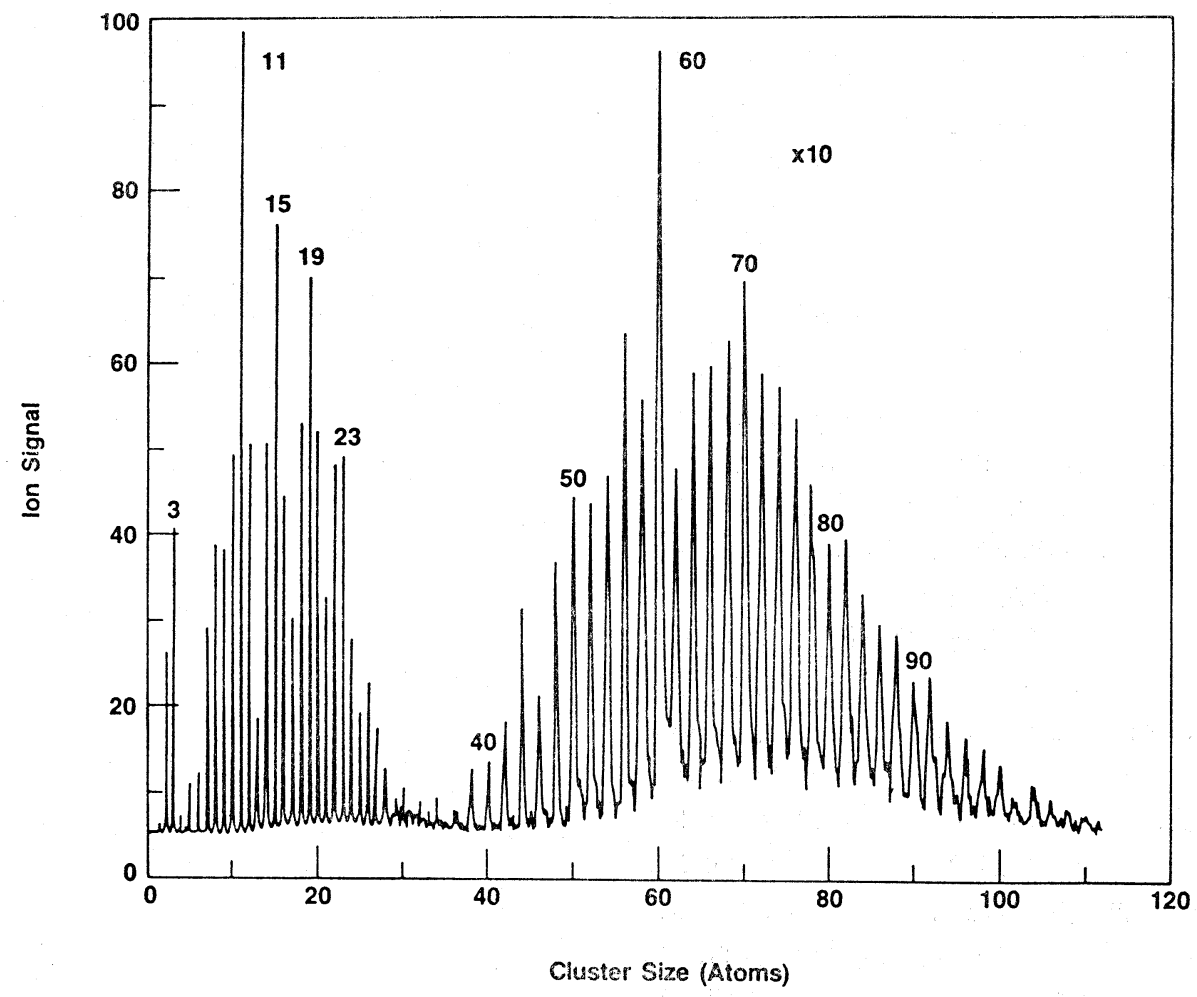

Fig. 14 Time-of-flight mass spectra for carbon clusters obtained with $40 \mathrm{~mJ}$ doubled $\mathrm{Nd}$ : YAG vaporizing laser energy and with $1.6 \mathrm{~mJ}$ unfocused $\operatorname{ArF}(193 \mathrm{~nm})$ ionizing laser energy. This spectrum is a combination of two diffesent spectra. For $C_{n}{ }^{+}, 1 \leqq n \leqq 30$, the vertical deflection plate voltage used $300 \mathrm{~V}$ which oftimized $C_{20}^{+}$collection while for $C_{2 n}^{+}, 20 \leqq n \leqq 50,600 \mathrm{~V}$ was used, optimizing $C_{100}^{+}$. The gain in the latter instance was also increased by a factor of 10 . The signal intensities of the two distributions cannot be compared directly since the small clusters are two-photon ionized while the large clusters are single photon ionized [Ref. 64].

(Rohlfing et al.: J. Chem. Phys. 81, 3322 (1984), Fig. 1) 


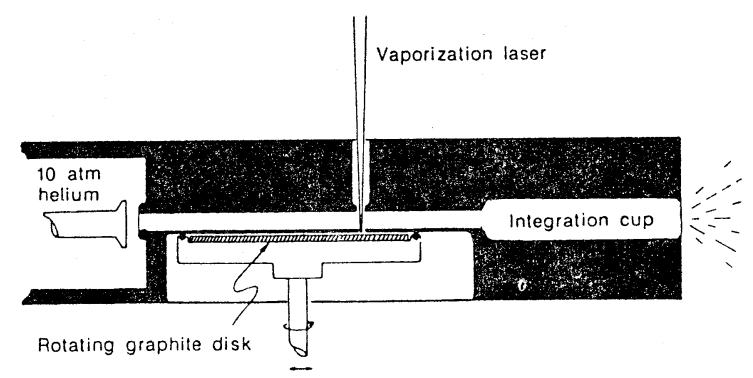

Fig. 15 Schematic diagram of the pulsed supersonic nozzle used to generate carbon cluster beams. The vaporization lasar beam $(30-40$ $\mathrm{mJ}$ at $532 \mathrm{~nm}$ in a 5 -ns pulse) is focused through the nozzle, striking a graphite disk which is rotated slowly to produce a smooth vaporization surface. The pulsed nozzle passes high-density helium over this voporization zone. This helium carrier gas provides the thermalizing collisions necessary to cool, react and cluster the species in the vaporized graphite plasma, and the wind necessary to carry the cluster products through the remainder of the nozzle. Free expansion of this cluster-laden gas at the end of the nozzle forms a supersonic beam which is probed $1.3 \mathrm{~m}$ downstream with a time-offlight mass spectrometer [Ref. 65].

(Kroto et al.: Nature 318, 162 (1985), Fig. 2)

一の質量スペクトルにも見出すことができる．この $\mathrm{C}_{60}$ の構造としては, 対称性の高いサッカーボールの形(Fig. 17）が Krotoら ${ }^{65}$ とよって提案されている，nの大さい クラスターでのイオン化ポテンシャルがグラファイトの それに近づき約 $5 \mathrm{eV}$ となるという Rohlfing らの結果 と考觉あわせると， $\mathrm{n}=60$ 以外の他の $\mathrm{n}$ のきいクラス ターについても球状の共鳴構造を伴うものであることが 推定される. また, $\mathrm{C}_{\mathrm{n}}$ と $\mathrm{NO}, \mathrm{SO}_{2}$ ・の反応性について の研究が行われ ${ }^{68)}, \mathrm{C}_{60}$ は非常に反応性が低いことがわ かった. 一方, $\mathrm{C}_{\mathrm{n}}$ クラスターの負イオン質量スペクトル を測定すると， C-

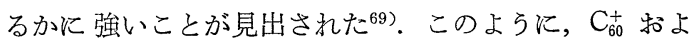
び $\mathrm{C}_{60}^{-}$の両方のイオンが非常に安定であることから， $\mathrm{C}_{60}$ が際立って安定であること予想される。 $\mathrm{C}_{60}$ が Fig. 17 のような構造をとる場合, 球の中央に直径 $7 \AA$ 程の空隙 があることがわかる. Heathら ${ }^{70} は, \mathrm{LaCl}_{3}$ の水溶液で 処理したグラファイトを用いることにより， $\mathrm{LaC}_{60}$ の質 量スペクトルを見出し，その空隙に La 原子がはめこま れた化合物の存在を予想している． $\mathrm{LaC}_{60}$ については, Cox ら $\left.{ }^{71}\right)$ もとの質量スペクトルをさらにくわしく測定し ている.

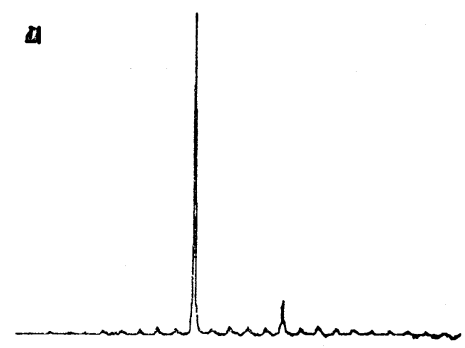

$b$

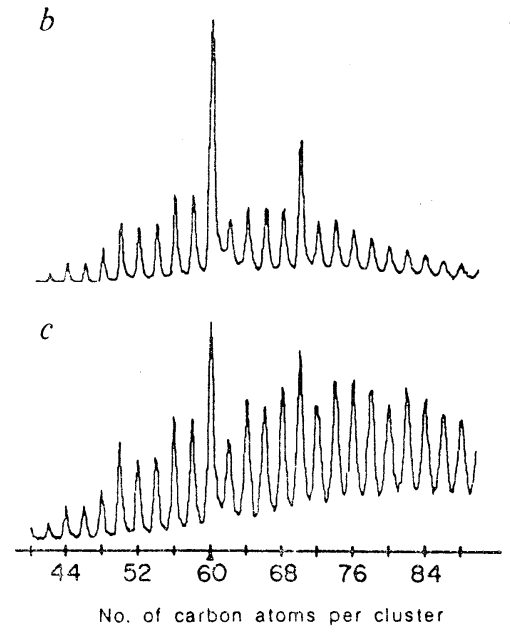

Fig. 16 Time of flight mass spectra of carbon clusters prepared by laser vaporization of graphite and cooled in a supersonic beam. Ionization was effected by direct one-photon excitation with an $\mathrm{ArF}$ excimer laser $(6.4 \mathrm{eV}$, $\left.1 \mathrm{~mJ} / \mathrm{cm}^{2}\right)$. The three spectra shown differ in the extent of helium collisions occurring in the supersonic nozzle. In (c), the effective helium density over the graphite target was less than 10 torr-the observed cluster distribution here is believed to be due simply to pieces of the graphite sheet ejected in the primary vaporization process. The spectrum in (b) was obtained when roughly 760 torr helium was present over the graphite target at the time of laser vaporization. The enhancement of $\mathrm{C}_{60}$ and $\mathrm{C}_{70}$ is believed to be due to gas-phase reactions at these higher clustering conditions. The spectrum in (a) was obtained by maximizing these cluster thermalization and cluster-cluster reactions in the 'integration cup' shown in Fig. 15 [Ref. 65].

(Kroto et al.: Nature 318, 162 (1985), Fig. 3)

共有結合クラスターについては, $\mathrm{Si}_{\mathrm{n}}, \mathrm{Ge}_{\mathrm{n}}, \mathrm{C}_{\mathrm{n}}$ の他飞 も, $\mathrm{S}_{\mathrm{n}}, \mathrm{Se}_{\mathrm{n}}, \mathrm{Te}_{\mathrm{n}}{ }^{72)}, \mathrm{As}_{\mathrm{n}} \mathrm{P}_{1-\mathrm{n}}{ }^{73)}, \mathrm{SiC}_{2}{ }^{74)}, \mathrm{Ga}_{\mathrm{n}} \mathrm{As}_{\mathrm{m}^{75)}}{ }^{75}$ どの報告がある 


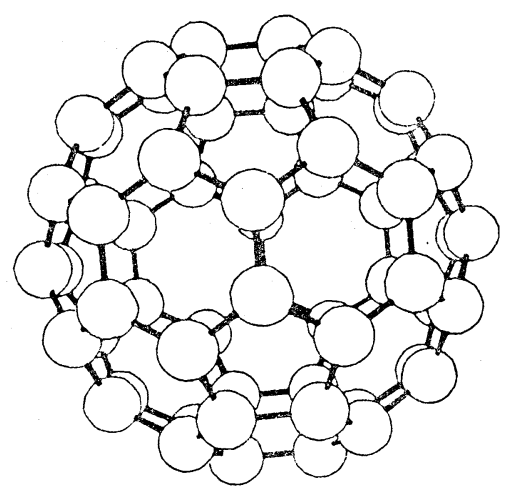

Fig. 17 An ORTEP drwaing of $\mathrm{C}_{60}$ [Ref. 67].

(Disch and Schulman: Chem. Phys. Lett. 125, 465 (1986), Fig. 1)

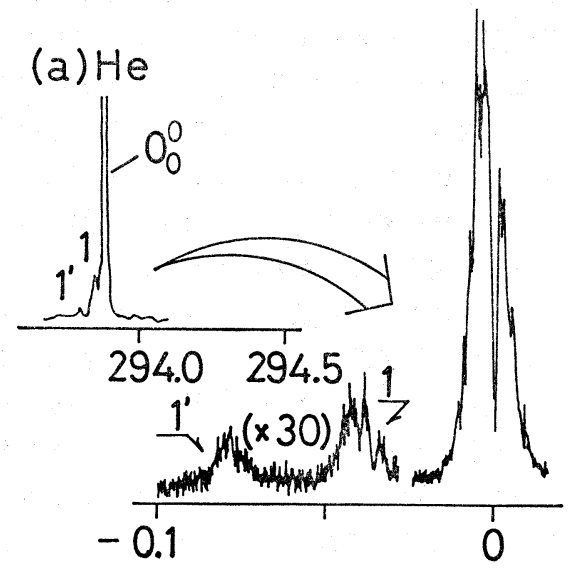

(c) $\mathrm{Ar}$

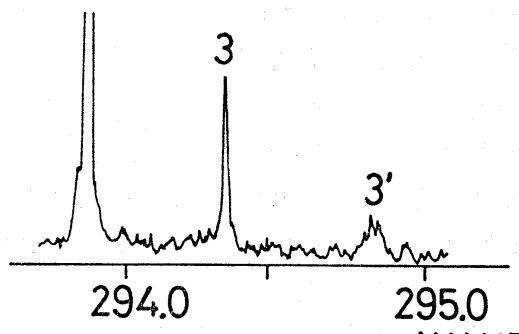

4. 分子クラスター

\section{1 分子クラスターの特徽}

希ガスのような閉款の電子構造を持つ原子や通常の分 子も，ノズルから真空中に噴出した超音速ジェット中で はクラスターを形成する，このよらなクラスターでは， その構成原子・分子間の結合はファンデルワールス結合 などの弱い結合であるため，分子が異方性を持つ場合に は，その分子の配向する方向によって安定化エネルギー のほぼ等しい複数の異性体が存在すると考光られる. 弱 く異方的な結合, 異性体の存在などがクラスタ一の構造 や反応性に対してどのような役割を持っているかを示す いくつかの例を以下に述べる.

\section{2 分子クラスターの構造}

超音速ジェット中で生成した分子クラスターの構造を 調べるには，(1）分子線電場共鳴法，（2）フーリェ変換 マイクロ波分光法，（3）レーザー誘起螢光 (LIF) 法など

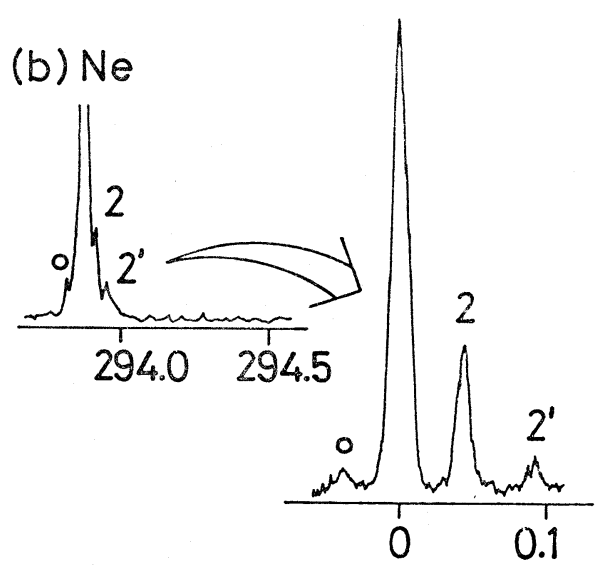

\section{(d) $\mathrm{Kr}$}

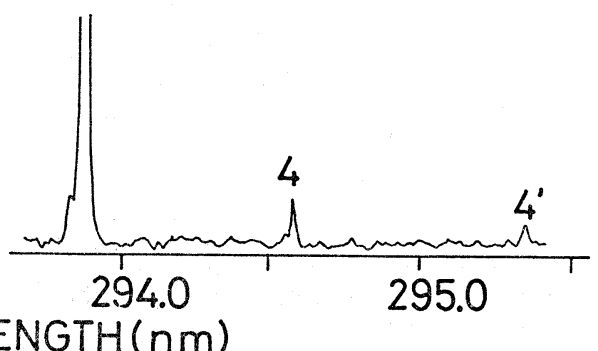

Fig. 18 Low-resolution LIF spectra of the $0_{0}^{0}$ band for aniline and its vdW complexes with one rare gas atom (peaks $1-4$ ) and those with two rare gas atoms (peaks $2^{\prime}-4^{\prime}$ ). Peaks 1 and $1^{\prime}$ are assigned to the transition to the $v^{\prime}=1$ and $v^{\prime}=2$ states of the $\mathrm{vdW}$ bond stretching mode of the He-aniline complex, respectively, and a peak, $O$ is assigned to that to the $v^{\prime}=1$ state of the Ne-aniline complex. 
の手法が用いられている。ここでは，(3) のLIF 法を用 いた研究を紹介する，この方法は，電子基底状態ばかり でなく, 電子励起状態でのクラスターの構造も決定でき るという特色がある。また，溶液中の電子スペクトルに 見られる溶媒効果を溶媒分子を含んだ分子クラスターの 電子スペクトルを調ベることにより明らかにすることが でさる。したがって，溶媒効果という巨視的な現象を分 子間力といら微視的な量に結びつけるとになる。なか でも，芳香族化合物に希ガスが付着したクラスターは， 分子間相互作用を調べるための最も単純なこデルであ り, 実験的・理論的に多くの研究が行われている.われ われは，そのよらなクラスターとしてアニリン希ガスク

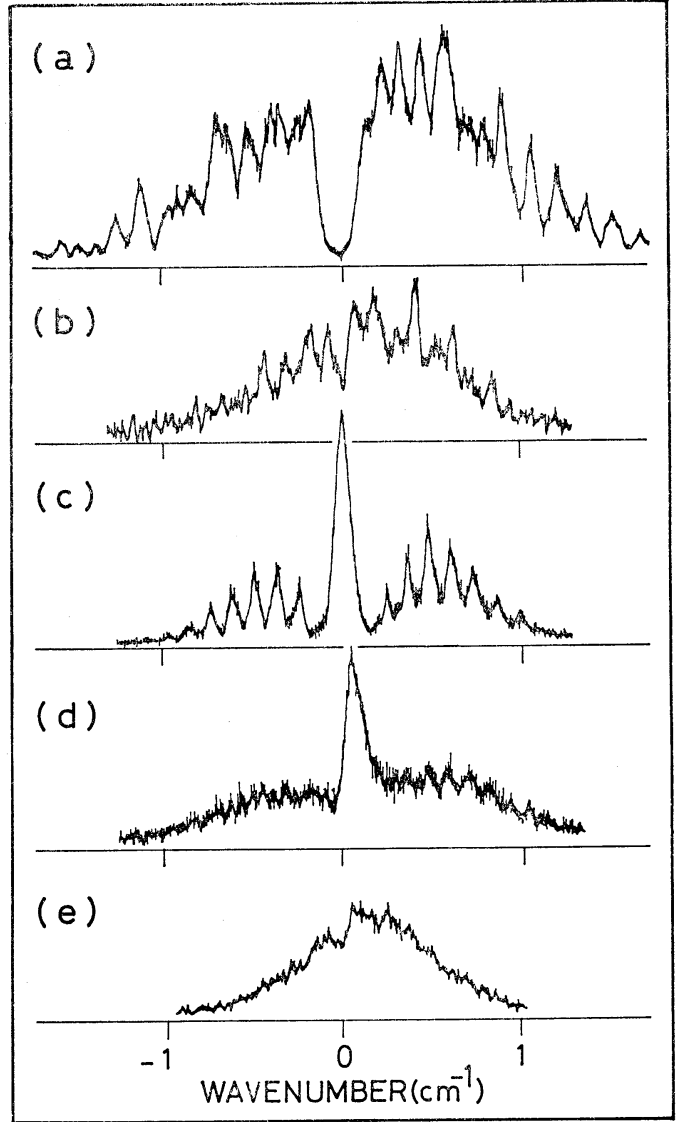

Fig. 19 Rotational structure for the $0_{0}^{0}$ transition of (a) aniline in a supersonic free jet and those for (c) Ne-aniline, (d) Ar-aniline, and (e) Kr-aniline van der Waals complexes. For the He-aniline complex, its rotational structure (b) is that for the transition to the $v^{\prime}=$ 1 state of a van der Waals bond stretching: mode. The rotational temperature is in the range between $1.0-1.5 \mathrm{~K}$.
ラスターをとりあげ，その構造と波長シフトについて研 究した

アニリンの基底状態 $\mathrm{S}_{0}\left(\widetilde{\mathrm{X}}^{1} \mathrm{~A}_{1}\right)$ から励起状態 $\mathrm{S}_{1}\left(\widetilde{\mathrm{A}}^{1} \mathrm{~B}_{2}\right)$ への $0_{0}^{0}$ 遷移は， $293.7 \mathrm{~nm}$ にある. He などの希ガスに 微量のアニリン（０.5 Torr）を混合し，よどみ圧 2 atm で直径 $d$ が $400 \mu \mathrm{m}$ のパルスノズルから真空中に 澒出した。，ズルから下流への距離 $x$ が約 $10 \mathrm{~mm}$ の ところで分子流に垂直に紫外レーザー光を照射し，レー ザー波長を掃引しながら LIF を測定した。この分子流 中には，アニリンの他にシードに用いた希ガスとアニリ ンとのクラスターが存在する. クラスターの形成に伴ら 安定化の程度が $\mathrm{S}_{0}$ 状態と $\mathrm{S}_{1}$ 状態で買なるため, クラ スターの $0_{0}^{0}$ 遷移は Fig. 18 に示すよらにアニリンの $0_{0}^{n}$ 遷移と異なる波長に钼測される. Fig. 18 の波長シフト したピーク $(1 〜 4)$ を高分解能 $\left(0.04 \mathrm{~cm}^{-1}\right)$ で測定した ところ, Fig. 19 に示すようなそれぞれのクラスターに 固有な回転構造を得た。これらの回転構造の解析ふら, Fig. 18 の 1〜4 のピークはいずれもアニリンに希ガス 1 原子が付着したクラスターの遷移であり, Fig. 20 に 示す簡単なモデルを用いてクラスターの構造が表わされ ること, 末た, Heを除く希ガス原子とのクラスターで は, $\mathrm{S}_{1}$ 状態でのファンデルワールス結合距離 $R$ が $\mathrm{S}_{0}$ 状態のときよりも $0.1 \AA$ 程度短いことがわかった. 波長 シフトが長波長側であり，その大きさが希ガスの分極率 にほぼ比例することを考慮すると, $\mathrm{S}_{1}$ 状態でのファンデ ルワールスカは $\mathrm{S}_{0}$ 状態のときより大きく，その結果と して平衝核間距離も短くなると考えられる. $\mathrm{S}_{0}$ と $\mathrm{S}_{1}$ で の $R$ が異なることは, 他の希ガス芳香族分子クラスタ 一でも見出されている79-83). また, 希ガスの分極率と波 長シフトの関連は, さまざまな希ガス芳香族分子クラス ターで報告されて扣り ${ }^{84-89)}$, 分散力の寄与を見積る近似

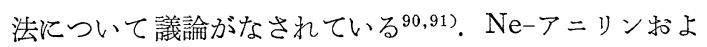
びAr-アニリンクラスターでは, 回転構造の解析により 傾きの角度 $\theta$ (Fig. 20参照)をそれぞれ $8(4)^{\circ}, 10(8)^{\circ}$ と 求めた. これは，希ガスとアミノ基との間にも弱い引力 相互作用があることを示している．類似のファンデルワ ールス結合の傾きについては, Ar-フラン92), Ar-フルオ レン93)クラスターについて報告がなされている. Fig.19 に示した回転構造は, いずれもクラスターの回転温度が $2 \sim 1 \mathrm{~K}$ 程度と極低温であることを示している.アニリン 単量体の回転構造を $x / d$ の值を変化させて測定したとこ ろ, $x / d \geq 2$ の領域ですでに回転温度は $5 \mathrm{~K}$ 以下となる ことがわかった ${ }^{77}$.

最近われわれは，アニリンを $\mathrm{H}_{2}, \mathrm{~N}_{2}, \mathrm{CH}_{4}$ などの無 極性分子とのクラスターを前述と同様の方法で生成し, 


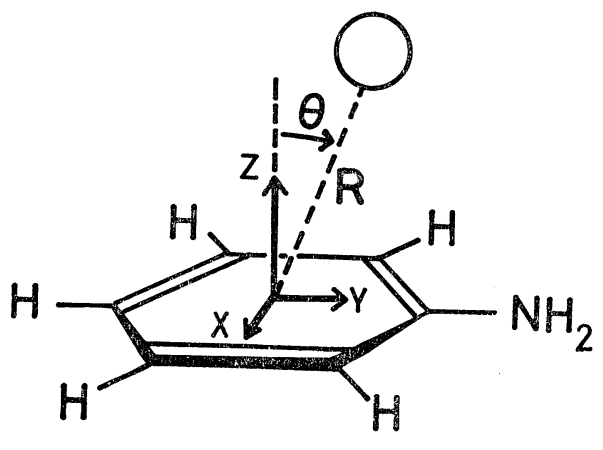

Fig. 20 A structural model for a rare gas-aniline complex. The rare gas atom is expressed by a circle on the $\mathrm{Y}-Z$ plane; $\theta$ is the angle between the $Z$ axis and the line connecting the origin and the rare-gas atom, the positive direction being taken as shown, and $R$ represents the van der Waals bond length.

その LIF スペクトルを測定した ${ }^{94)} . \mathrm{N}_{2}$-アニリン錯体の 場合には，アニリンに $N_{2}$ 分子が 1 個付着したクラスタ 一に帰属できるピークが $2 つ$ 見出された. 波長シフトと $\mathrm{N}_{2}$ 分子の分極率とを考光あせると， $\mathrm{N}_{2}$ 分子のアニリ ンに対する方向が暴なる 2 つの異性体の存在が示唆され た. すなわち, $\mathrm{N}_{2}$ 分子の 2 つの窒素原子を結ぶ軸が, アニリンのベンゼン環のつくる平面に垂直な異性体と平 行な異性体の 2 つである. このような異性体を伴うファ ンデルワールスクラスターとしては, Levy らのグルー

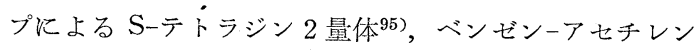
クラスター93)が知られている. 芳香族分子を含むファン デルワールスクラスターでの異性体の構造については,

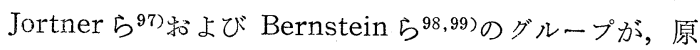
子対ポテンシャルを計算することによって推定してい る. しかし，これらのクラスターにみられる浅く異方的 な分子間ポテンシャルを定量的に見積ることは難しいと 思われる.

芳香族分子を含むクラスターとしては，ファンデルワ ールスクラスターの他に, 水素結合クラスターがあり, 伊藤らのグループによって，インドールージオキサン100), フェノールー水, フェノールーベンゼン101)などの水素結合 クラスター系が調べられている. この他, 最近では, $\mathrm{Hg}$ 原子と希ガス 102-105), メトキシラジカルと A $\mathrm{r}^{103)}$, 9-シアノアントラセンと希ガス ${ }^{107)}, \mathrm{H}_{2} \mathrm{O}$ 二量体(108)など の分子クラスターが研究されている. また，尾崎らは， $\mathrm{Ar}_{2}$ や $\left(\mathrm{CO}_{2}\right)_{2}$ などの二量体クラスターの生成について 報告している109).

\section{3 分子クラスターの電子移動過程と反応過程}

分子クラスターの場合には, 分子間の相互作用が弱い
ので，構成分子は比較的独立しているように見える. し かし，この分子間力のために，クラスター内に祌ける反 応には，孤立分子系の反応（気相反応）では見られない 特徵が導入される. これは，構成分子が相互に働く分子 間力を通じて影響を及ぼしあっているために起こるもの であり，一種の協力現象である. クラスター内反応の特 徵は，気相中の反応のように，他の分子が偶然に衝突し てくるのを待つのではなく，必要な反応分子をクラスタ 一の中にあらかじめ入れておく (built-in)ことができる という点である. したがって，三体反応や溶媒効果が顕 著になるような反応がクラスター中で効率よく進行する と予想でさる.

その built-in の例として，梶本ら ${ }^{110}$ による NO のフ アンデルワールス二量体の 光解離過程の 研究がある.

$193 \mathrm{~nm}$ の光を用いると, $(\mathrm{NO})_{2}$ は解離して $\mathrm{NO*}(\mathrm{A})$ および $\mathrm{NO}^{*}$ (B) が $1: 2$ の割合で生成することがわかっ た. このことは, NO-NO* (A) と NO-NO* (B) の $2 つ$ のポテンシャルが交差していることを示している. 三体 反応の例としては同著者による $\mathrm{O}+(\mathrm{NO})_{2} \rightarrow \mathrm{NO}_{2}{ }^{*}+\mathrm{NO}$ の反応 ${ }^{110)(b)}$ が，溶媒効果の例としては $9,9^{\prime}$-bianthryl について研究110)(c)がある。 また, Castleman ら ${ }^{111) の ク ゙ ~}$ ループは，分子線電場共鳴法と質量分析法と組みあわせ ることにより, $\mathrm{SO}_{3}$ 分子が水のクラスター $\left(\mathrm{H}_{2} \mathrm{O}\right)_{\mathbf{n}}$ と反 応する過程を調べた。 その過程は,

$$
\begin{aligned}
\left(\mathrm{H}_{2} \mathrm{O}\right)_{\mathbf{n}}+\mathrm{SO}_{3} & \longrightarrow\left(\mathrm{H}_{2} \mathrm{O}\right)_{\mathrm{n}_{-1}}\left(\mathrm{H}_{2} \mathrm{O} \cdot \mathrm{SO}_{3}\right) \\
& \stackrel{\text { 異性化 }}{\longrightarrow}\left(\mathrm{H}_{2} \mathrm{O}\right)_{\mathrm{n}-1}\left(\mathrm{H}_{2} \mathrm{SO}_{4}\right)
\end{aligned}
$$

で示され， $\mathrm{H}_{2} \mathrm{O}$ が配位している状態で $\mathrm{H}_{2} \mathrm{O} \cdot \mathrm{SO}_{3}$ が効率 よく $\mathrm{H}_{2} \mathrm{SO}_{4}$ に異性化されていると報告している.

クラスター内の反応の特徵的ふるまいは，イオン化に 伴う緩和過程にも見出される. 質量分析法を用いてクラ スターを検出するには，クラスターをイオン化する必要 があるが，このイオン化に伴い，分解やbuilt-in 型のイ オンー分子反応などの緩和過程が起こる. この緩和過程 は，以下に示すように，正イオンが生成する場合と負イ オンが生成する場合とで顕著に異なっている.

\subsection{1 クラスター正イオンの生成と緩和・ 反応}

電子衝撃や光などによってクラスターをイオン化する と，かなりの確率で解離や反応が起こる. Echt と Recknagel ら ${ }^{112}$ は, キセノンクラスター $(\mathrm{Xe})_{\mathrm{n}}$ を電子 衝撃によってイオン化し，イオンの解離過程,

$$
\begin{aligned}
& (\mathrm{Xe})_{\mathrm{n}}+\mathrm{e} \longrightarrow(\mathrm{Xe})_{\mathrm{n}^{+}+\mathrm{e}} \\
& (\mathrm{Xe})_{\mathrm{n}}{ }^{+} \longrightarrow(\mathrm{Xe})_{\mathrm{m}^{+}}+(\mathrm{n}-\mathrm{m}) \mathrm{Xe}
\end{aligned}
$$

を調べた，彼らは，reflectron 質量分析計を用いて，親 
イオン $(\mathrm{Xe})_{\mathrm{n}}{ }^{+}$中に含まれる娘イオン $(\mathrm{Xe})_{\mathrm{m}}{ }^{+}$を飛行時 間の差を利用して除去し，親イオンのみによる質量スペ クトルを得た. その結果, $(\mathrm{Xe})_{57}+$ が $99 \%$ 解離するのに 対して, $\mathrm{n}=13,19,25$ のクラスターイオンはあまり解離 しないことがわかった，そのため，質量スペクトル上で は, $\mathrm{n}=13,19,25$ の強度が大きく, $\mathrm{n}=57$ ではピークが ほとんど観測されない. クラスターイオンが安定である これらの $\mathrm{n}$ の值, $13,19,25$ はジック数と考学らる. このよらなクラスターイオンの解離にみられる $\mathrm{n}$ 依存性 は， $\mathrm{H}_{2} \mathrm{O}$ の分子クラスターでも観測されている ${ }^{113)}$. ま た, $\mathrm{H}_{2} \mathrm{O}$ や $\mathrm{NH}_{3}$ などの水素を含んだ分子からなるクラ スターでは， $\mathrm{H}^{+}$を含んだクラスターイオンが多く見ら れる114)。これは，クラスタ一内に和壮るイオン分子反応 の結果である.

最近 Bernsteinら ${ }^{115)}$ は, $\left(\mathrm{CH}_{3} \mathrm{~F}\right)_{\mathrm{n}}$ を電子衝撃してイオ ン化すると, カスケード型のクラスター内イオン分子反 応が起こると報告している.すなおち，

$$
\begin{gathered}
\left(\mathrm{CH}_{3} \mathrm{~F}\right)_{\mathrm{n}}+\mathrm{e} \longrightarrow\left(\mathrm{CH}_{3} \mathrm{~F}\right)_{\mathrm{n}-1} \mathrm{CH}_{3} \mathrm{~F}^{+}+2 \mathrm{e} \\
\left(\mathrm{CH}_{3} \mathrm{~F}\right)_{\mathrm{n}-2}\left(\mathrm{CH}_{3} \mathrm{~F}+\mathrm{CH}_{3} \mathrm{~F}^{+}\right) \\
\quad \longrightarrow\left(\mathrm{CH}_{3} \mathrm{~F}\right)_{\mathrm{n}_{-2}} \mathrm{CH}_{3} \mathrm{FH}^{+}+\mathrm{CH}_{2} \\
\left(\mathrm{CH}_{3} \mathrm{~F}\right)_{\mathrm{n}-3}\left(\mathrm{CH}_{3} \mathrm{~F}+\mathrm{CH}_{3} \mathrm{FH}^{+}\right) \\
\quad \longrightarrow\left(\mathrm{CH}_{3} \mathrm{~F}\right)_{\mathrm{n}-3}\left(\mathrm{CH}_{3} \mathrm{FCH}_{3}\right)^{+}+\mathrm{HF} \\
\left(\mathrm{CH}_{3} \mathrm{~F}\right)_{\mathrm{n}-3}\left(\mathrm{CH}_{3} \mathrm{FCH}_{3}\right)^{+} \\
\longrightarrow\left(\mathrm{CH}_{3} \mathrm{~F}\right)_{\mathrm{n}-3}\left(\mathrm{CH}_{2} \mathrm{~F}\right)^{+}+\mathrm{CH}_{4}
\end{gathered}
$$

となる.このことは，クラスター内のイオン一分子反応 では，気相のイオン分子反応とは異なって，クラスター 内部での多重衝塋が起こることを示している，なた，驚 田 ${ }^{116)}$ は，シクロヘキサン (cyclo- $\left.\mathrm{C}_{6} \mathrm{H}_{12}\right)$ とアセチレン $\left(\mathrm{C}_{2} \mathrm{H}_{2}\right)$ との 1:1 ヘテロクラスターをつくり, $10.03 \mathrm{eV}$ の真空紫外光を用いて cyclo- $\mathrm{C}_{6} \mathrm{H}_{12}$ のみをイオン化し, 以下の反応が起こることを質量スペクトルにより確認し た (Fig. 21):

$$
\text { cyclo- } \mathrm{C}_{6} \mathrm{H}_{12}{ }^{+} \longrightarrow \text { cyclo- } \mathrm{C}_{6} \mathrm{H}_{11}{ }^{+}+\mathrm{C}_{2} \mathrm{H}_{3}
$$

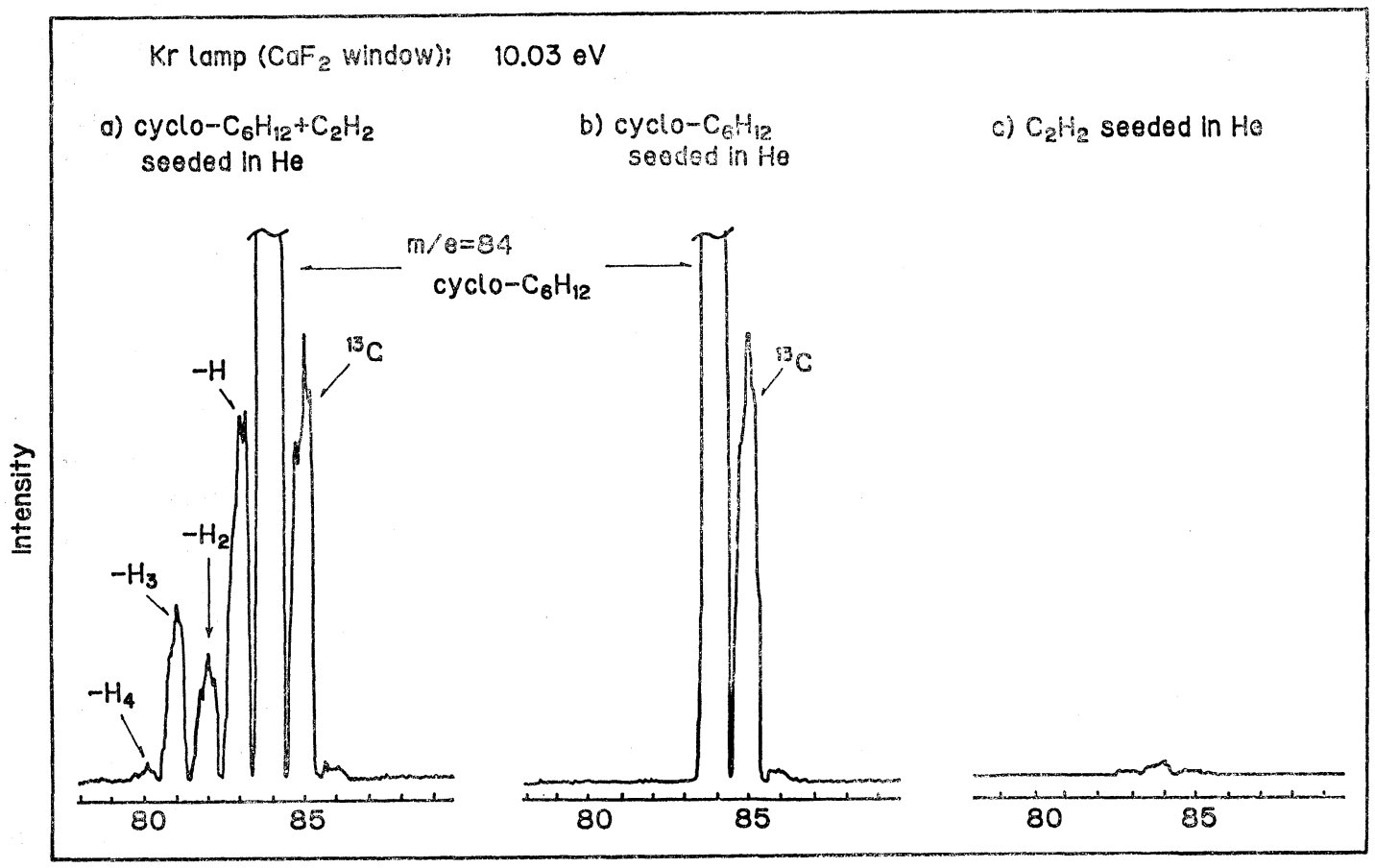

Mass Number

Fig. 21 A sample gas, cyclo- $\mathrm{C}_{6} \mathrm{H}_{12}+\mathrm{C}_{2} \mathrm{H}_{2}$, cyclo- $\mathrm{C}_{6} \mathrm{H}_{12}$, or $\mathrm{C}_{2} \mathrm{H}_{2}$ seeded in $\mathrm{He}$ gas which was expanded through a nozzle into a vacuum chamber and was ionized by a Kr-resonance radiation. A variety of de-hydrogenated ions of cyclo- $\mathrm{C}_{6} \mathrm{H}_{12}$ are observed in the mass spectra, arising from intracluster ion-molecule reactions between cyclo- $\mathrm{C}_{6} \mathrm{H}_{12}^{+}$and $\mathrm{C}_{2} \mathrm{H}_{2}$ (panel (a)). As shown in panels (b) and (c), the Kr-resonance radiation can ionize cyclo$\mathrm{C}_{6} \mathrm{H}_{12}$, but not $\mathrm{C}_{2} \mathrm{H}_{2}$. 


$$
\begin{aligned}
& \longrightarrow \text { cyclo- } \mathrm{C}_{6} \mathrm{H}_{10}{ }^{+}+\mathrm{C}_{2} \mathrm{H}_{4} \\
& \longrightarrow \text { cyclo- } \mathrm{C}_{6} \mathrm{H}_{9}{ }^{+}+\mathrm{C}_{2} \mathrm{H}_{5} \\
& \longrightarrow \text { cyclo- } \mathrm{C}_{6} \mathrm{H}_{8}{ }^{+}+\mathrm{C}_{2} \mathrm{H}_{6}
\end{aligned}
$$

気相中のイオン分子反応では， cyclo- $\mathrm{C}_{6} \mathrm{H}_{12}{ }^{+}$から最大 2 個のHを引抜く反応しか起こらないが，クラスター内の 反応では，ここで示したように，Hが 3 個以上引抜かれ る反応が効率よく進んでいる，このことから，式(13)， （14）で表わされる反応は，クラスター内部での 2 回以上 の衝突によって進行すると推定される．アセチレンのか わりにェチレンを用いたへテロクラスターや，クラスタ 一を生成するときのシード気体による効果についても検 討されている.

\subsection{2 クラスターへの電子付着による負イオン生} 成

中性のクラスター， $(\mathrm{M})_{\mathrm{n}}$ に電子を付着させるとクラ スター負イオン， $(\mathrm{M})_{\mathrm{n}}{ }^{-}$が生成する. この電子付着過程 に和村る断面積や緩和過程は, 付着電子の運動エネルギ 一やクラスターの垂直電子親和力, $\mathrm{EA}_{\mathrm{v}}$ などに強く依存 している. 一般的には，EA $>0$ で電子の運動エネルギ 一が小さいと, 電子付着の断面積が大きくなり, 電子付 着に伴ら緩和も特だやかに起こる．たとえば，筫野ら のグループは放射線で低速電子線をつくり， $\mathrm{O}_{2}$ クラスタ 一などに電子を付着する実験を行なっている，一方；著 者らは，主量子数が 20-40の高いリュードベリ状態にあ る希ガス原子 $\left(\mathrm{Rg}^{* *}\right)$ の最外款電子(リュードベリ電子) が， $20 \mathrm{meV}$ 程度の非常に小さな運動エネルギーを持 つことに着目し，

$$
(\mathrm{M})_{\mathrm{n}}+\mathrm{Rg}^{* *} \longrightarrow(\mathrm{M})_{\mathrm{n}^{-}}+\mathrm{Rg}^{+}
$$

と表わされる反応によってクラスター負イオンを生成す る実験をすすめている ${ }^{2,117)}$ ，ここで， $\mathrm{Rg}^{* *}$ は超低速の 電子線とみなすことができるので118), 電子移動過程 (15) は,

$$
(\mathrm{M})_{\mathrm{n}}+\mathrm{e} \longrightarrow(\mathrm{M})_{\mathrm{n}^{-}}
$$

と同等である. Fig. 22 は実験装置の概略図であり, $\mathrm{Rg}^{* *}$ と $(\mathrm{M})_{\mathrm{n}}$ との衝突イオン化は，Fig. 23 のよらなイオン 化室で行う.

$\mathrm{Rg}^{* *}$ によるイオン化過程は，用いるクラスターの構 成分子Mの性質によって以下のつの場合に分類される.

i）電子付着に伴ら安定化エネルギーはクラスターイオ ン, $(\mathrm{M})_{\mathrm{n}}{ }^{-}$の内部自由度に分配されて安定化する $(\mathrm{M}=$ $\mathrm{CH}_{3} \mathrm{CN}, \mathrm{SF}_{6}, \mathrm{C}_{6} \mathrm{H}_{5} \mathrm{~N}$ (ピリジン)). ii) 安定化エネルギ 一が分子間の自由度に分配されて，蒸発が，

$$
(\mathrm{M})_{\mathrm{n}^{-}} \longrightarrow(\mathrm{M})_{\mathrm{m}^{-}}+(\mathrm{n}-\mathrm{m}) \mathrm{M}
$$

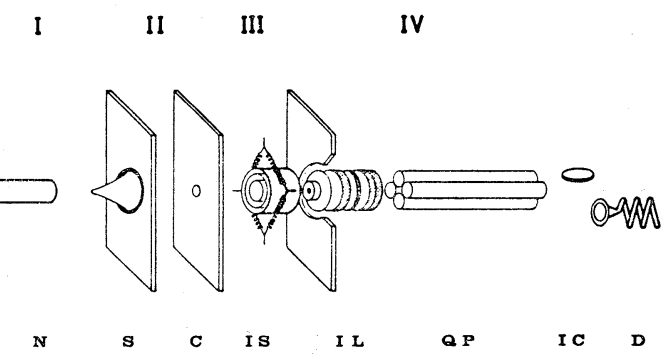

Fig. 22 Schematic diagram of the apparatus. Four vacuum chambers are differentially pumped. A sample gas was expanded from a nozzle (N). Supersonic cluster beam was extracted through a skimmer (S) and a collimator (C). The cluster ions produced in a concentric triple-grid ion source (IS) were focused by ion lenses (IL) and mass-analyzed by a quadrupole mass spectrometer (QP). Negative ions were converted by an ion conversion dynode (IC) and detected by a Ceratron electron multiplier (D).

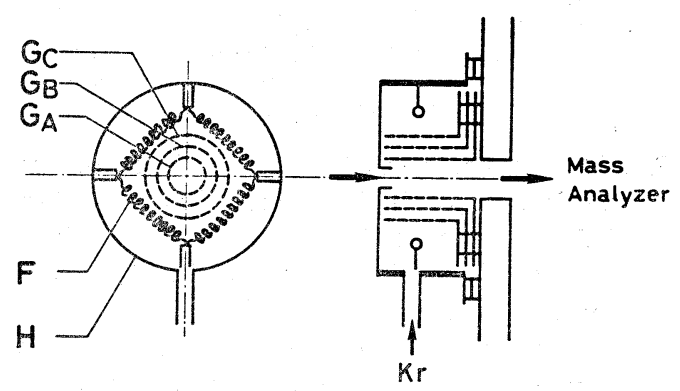

Fig. 23 A side view (right) and a front view (left) of the ion source. Krypton gas is excited by impact of electrons emitted from four filaments (F). Three concentric grids, $\mathrm{G}_{\mathrm{A}}, \mathrm{G}_{\mathrm{B}}$, and $\mathrm{G}_{\mathrm{C}}$, are installed in a housing $(\mathrm{H})$ of the ion source for preventing ionic species and electrons from entering the central region surrounded by $G_{A}$. A cluster beam passes along the axis of the ion source and collides with high-Rydberg krypton atoms in the central region.

のように起こる $\left(\mathrm{M}=\mathrm{CO}_{2}, \mathrm{OCS}, \mathrm{CS}_{2}\right)$. iii) 安定化ェネ ルギーを用いてクラスター内反応が起こる（ $\mathrm{M}=\mathrm{N}_{2} \mathrm{O}$, $\mathrm{CCl}_{4}$ など).

クラスター $(\mathrm{M})_{\mathrm{n}}$ の $\mathrm{EA}_{\mathrm{v}}$ 值は, $\mathrm{n}$ とともに増加する ので, 単量体 $\mathrm{M} の \mathrm{EA}_{\mathrm{v}}$ 值が負の場合でも，あるサイズ $\mathrm{n}_{\mathrm{L}}$ 以上でクラスタ一負イオンが観測される. Fig. 24 に 示す $\mathrm{M}=\mathrm{CH}_{3} \mathrm{CN}$ の負イオン質量スペクトルは最も典 型的な例である. $\mathrm{CH}_{3} \mathrm{CN}$ の単量体は $\mathrm{EA}_{\mathbf{V}}<0$ である 


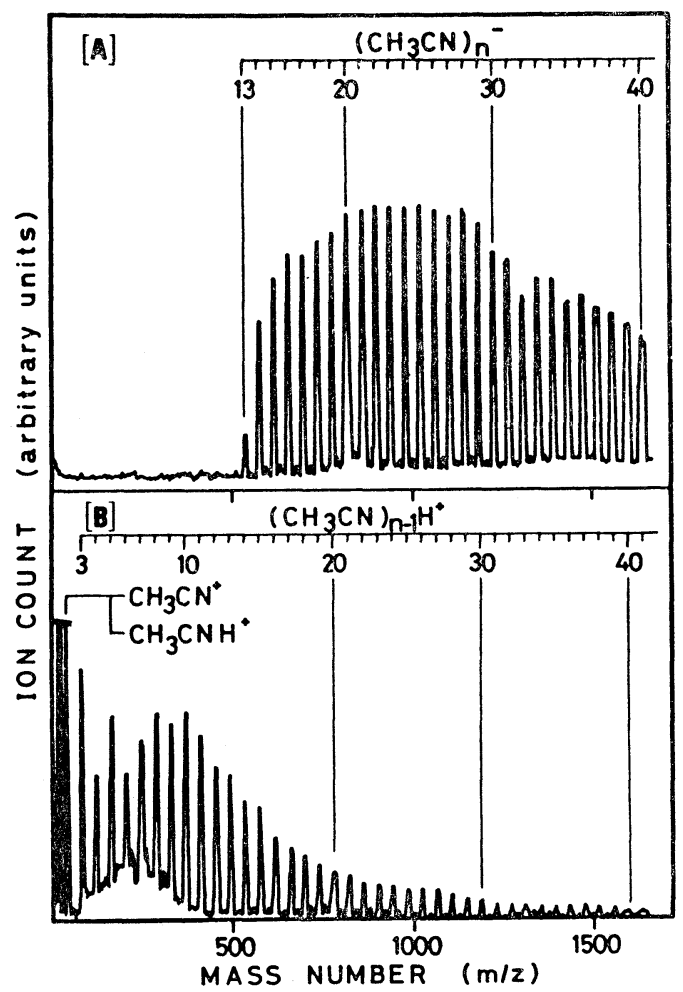

Fig. 24 Mass spectra of the cluster ions produced by impact of high-Rydberg krypton atoms [A] and electrons having an average kinetic energy of $50 \mathrm{eV}$ [B] on the $\mathrm{CH}_{3} \mathrm{CN}$ clusters formed in a supersonic nozzle beam at a stagnation pressure of 1250 Torr. The numbers above the ion peaks indicate the sizes of the cluster ions: $\left(\mathrm{CH}_{3} \mathrm{CN}\right)_{n}^{-}$[A] and $\left(\mathrm{CH}_{3} \mathrm{CN}\right)_{n-1} \mathrm{H}^{+}[\mathrm{B}]$.

が， $\mathrm{n}$ が大きくなるにつれて $\mathrm{EA}_{\mathbf{v}}$ は増加し， $\mathrm{n}=13$ で 正になる. この場合, 電子が付着しても安定化に伴らェ ネルギーが小さいので蒸発は起こらない(場合(i)). し たがって, 電子付着断面積のサイズ依存性を理論的に 計算することにより，( $\left(\mathrm{CH}_{3} \mathrm{CN}\right)_{\mathbf{n}}$ のサイズ分布を $\left(\mathrm{CH}_{3} \mathrm{CN}\right)_{\mathrm{n}}$ - 質量スペクトルから推定することができ る.

Fig. 25 に示したのは $\mathrm{M}=\mathrm{CO}_{2}, \mathrm{OCS}, \mathrm{CS}_{2}$ の場合の 質量スペクトルである. $\mathrm{CO}_{2}$ クラスターのサイズ分布の 解析から，イオン化に伴って 4 個以上の $\mathrm{CO}_{2}$ が蒸発す ると推定される. 一方, $\mathrm{CCl}_{4}$ クラスターの場合には, ク ラスター内イオンー分子反応によって, $\left(\mathrm{CCl}_{4}\right)_{\mathrm{n}} \mathrm{X}^{-}(\mathrm{X}=$ $\mathrm{Cl}, \mathrm{CCl}_{3}, \mathrm{CCl}_{2}$ など）が生成することが見出される. ま た， $\mathrm{N}_{2} \mathrm{O}$ クラスターでは，イオンー分子反応以外に $\left(\mathrm{N}_{2} \mathrm{O}\right)_{\mathrm{m}}{ }^{-}$も観測され，Rg** によるイオン化法が・ソフ

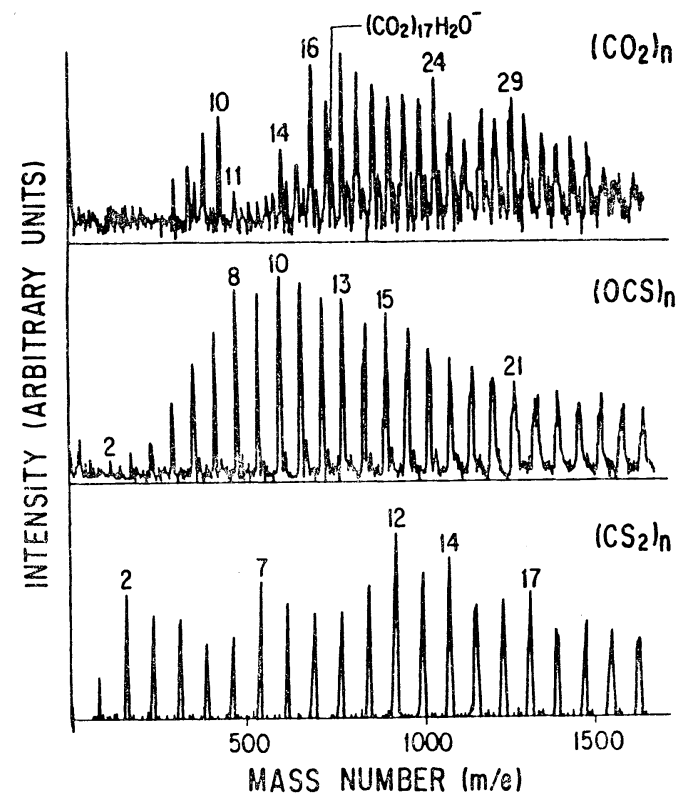

Fig. 25 The mass spectra of the negative cluster ion, $(\mathrm{M})_{m^{-}}$, produced from the neutral parent cluster, $(\mathrm{M})_{n}\left(\mathrm{M}=\mathrm{CO}_{2}\right.$, OCS, and $\left.\mathrm{CS}_{2}\right)$ in collision with $\mathrm{Kr}^{* *}$. Panels (a), (b), and (c) are the spectra for $\left(\mathrm{CO}_{2}\right)_{n},(\mathrm{OCS})_{n}$, and $\left(\mathrm{CS}_{2}\right)_{n}$, respectively.

ト’であることを示している，最近，この方法を用いて $\mathrm{H}_{2} \mathrm{O}$ クラスターから直接 $\left(\mathrm{H}_{2} \mathrm{O}\right)_{\mathrm{m}}$ 一を生成することを見 出した.このよらなクラスターイオンはこれまで電子付 着では直接生成できないと考えられていたものである.

低速電子 $(\sim 1 \mathrm{eV})$ を用い，多くのクラスターについて 同様な電子付着の実験を行なったところ，イオン化の断 面積が 4 桁以上小さくなること，また，余剩エネルギー が大きくなるためクラスターの分解が促進されることが 明らかになった。

\section{5. 結語}

以上に述べたように，現在では，クラスター分子線を レーザー分光法や質量分析法などの手法を用いて研究す ることにより, クラスター特有の性質が解明されつつあ る. ‘気相中に孤立した’状態にし，下地などの隣接する

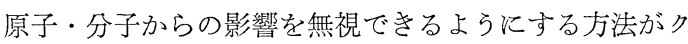
ラスター研究に導入されたのはここ数年のことであり, これから解決しなければならない問題点も多い. 以下 に，いくつかの将来の間題を指摘する.

まず緊急の課題のひとつは，サイズの揃ったクラスタ 一源を開発することである. 現在の分子線源ではサイズ 分布が広く, クラスターの凝縮法を改良しても完全に単 
一のサイズを持つクラスターとはならない119).クラスタ 一内緩和を十分に起こさせ，最も安定なエネルギーを持 つ異性体のみをつくる方法もサイズ制御の一種である. このような例として $\mathrm{C}_{60}$ クラスターがある65). クラスタ 一を他の粒子と衝突させたり ${ }^{120)}$, 不均一電場や磁場を用 いて特定のサイズを持ったクラスターを選別する方 法 $^{30-32,50)}$ も小さなクラスターに対しては有効であろう. クラスターイオンを質量分析したのち・中和する方法も 考它られるが, 中和する際の分解過程を吟味する必要が ある121,122).

クラスターの検出法としては，質量分析法が現在のと ころ一番有効であるので, 質量スペクトルによるクラス ターの研究は多い. 質量スペクトルを測定するためには クラスターをイオン化することが必要であるが，すでに 述べたように，その際クラスターが分解する可能性が高 い. したがって，中性クラスターに関するサイズ分布な どについての正しい情報を得るには，このイオン化過程 を十分に解析しなければならない、123). 中性クラスターの サイズ分布に対する影響を最小限に止めるためには，イ オン化法に対する工夫が必要となる：たと党ば高励起原 子を用いるイオン化法 ${ }^{117)}$ ，イオン化のしきい值と同じェ ネルギーを持つ光でイオン化する方法 ${ }^{124)}$ ，イオン化に伴 ら過剩エネルギーを吸収する第三体をあらかじめクラス ターに入れて括く方法125)などがある。

クラスターの構造や動的挙動を調ベるには，その電子 状態や振動・回転状態を知る必要がある. 二量体よりも 大きなクラスターの振動・回転状態に関しては, $\mathrm{Na}_{3}{ }^{126-}$ 128) や $\mathrm{Cu}_{3}{ }^{129,130)}$ についての報告があるが，四量体以上 のクラスターについてはまだ報告がない，分光学的アプ ローチによるクラスターの内部状態に関する研究は，方 法論の開発も含めて, 将来に残された重要課題である.

現段階でのクラスターの研究では，クラスターそのも のの 基本的性質を解明することに主眼が置かれている が，クラスターは気相と凝縮相の中間に位置し，特有な 性質を持つ物質系であるので, クラスターの研究で得ら れた成果は広く役立つものと思われる。たと充い゙，クラ スターは統計物理学的に見ると少数多体系のモデルとな り，また，核子クラスターである原子核とも類似の性質 があり，原子核の安定性や内部状態を考える手がかりを 与える.クラスター研究のその他の応用的側面としては, a) 半導体素子などの 微小化に 伴う問題点の解明, b) 反応分子とクラスター中にあらかじめ組み达んで，化学 反応を設計する方法の開発，c）クラスター内部の結合 とクラスター間の結合の持つ特性を生かして新しい物性 を持つ物質を合成する方法の開発，d）クラスターの “表面”での触媒反応の研究，e）エアロゾルの形成执よ びその表面での反応の解明，などが考えられる.

\section{謝 辞}

本総説を書くよう勧めて下さり, 内容について御意見 を下さった東京大学の朽津耕三教授拉よび土屋荘次教授 に感謝する.

\section{文献}

1) Chem. Rev. 86, 491-655 (1986) にクラスターの 化学に関する総説が 7 報収録されている.

2) T. Kondow : Electronic and Atomic Collisions, Eds. D. C. Lorents, W. E. Meyerhof and J.R. Peterson, Elsevier Science Publishers, p. 517 (1986).

3) Y. Hatano: Electronic and Atomic Collisions, Eds. D. C. Lorents, W.E. Meyerhof and J.R. Peterson, Elsevier Science Publihers, p. 153 (1986).

4) T.D. Mark and A.W. Castleman, Jr.: Adv. Atom Mol. Phys. 20, 65 (1985).

5) A.W. Castleman, Jr. and R. G. Keesee: Ann. Rev. of Phys. Chem., submitted.

6) J.A.A. J. Perenboom and P. Wyder: Phys. Report, 78, 173 (1981).

7) D. H. Levy: Ann. Rev. of Phys. Chem., 31, 197 (1980).

8）西 信之, 篠原久典, 西山岩雄 : “プラズマによる 物質合成と材料処理” 理化学研究所監修(アイオニ クス, 1984) p. 81.

9) 平岡賢三 : 化学の領域, 31巻, 48 (1977).

10) 梶本與亜, 土屋荘次 : レーザー 研究, 13巻, 690 (1985).

11) Surface Sci., 106; (1981) にローザンヌに拈ける クラスターの国際会議の内容が収録されている.

12) Surface Sci., 156, Part I, II (1985) にベルリンに 郝けるクラスターの 国際会議の内容が収録されて いる.

13) Ber. Bunsenges. Phys. Chem., 88 (1984) にクラ スターに関する文献が収録されている.

14) A. Herrmann, E. Schumacher, and L. Wöste: J. Chem. Phys., 68, 2327 (1978).

15) E. Schumacher, M. Kappes, K. Marti, P. Radi, M. Schär, and B. Schmidhalter : Ber. Bunsenges. Phys. Chem., 88, 220 (1984).

16) M. M. Kappes, R.W. Kunz, and E. Schumacher: Chem. Phys. Lett., 91, 413 (1982).

17) M. M. Kappes, M. Schär, P. Radi, and E. Schumacher: J. Chem. Phys., 84, 1863 (1986).

18) 加藤 肇 : 分光研究， 35，203 (1986).

19) E. J. Robbins, R. E. Leckenby, and P. Willis : Adv. Phys., 16, 739 (1967).

20) D. M. Wood: Phys. Rev. Lett., 46, 749 (1981).

21) C. Brechignac and $\mathrm{Ph}$. Cahuzac: Laser Chem. 
5, 321 (1986).

22) C. Brechignac and Ph. Cahuzac: Chem. Phys. Lett., 117, 365 (1985).

23) W.A. Saunders, K. Clemenger, W.A. de Heer, and W. D. Knight: Phys. Rev., B32, 1366 (1985).

24) K.I. Peterson, P.D. Dao, R.W. Farley, and A.W. Castleman, Jr.: J. Chem. Phys., 80, 1780 (1984).

25) W.D. Knight, K. Clemenger, W.A. de Heer, W. A. Saunders, M.Y. Chou, and M. L. Cohen : Phys. Rev. Lett., 52, 2141 (1984).

26) M.Y. Chou, A. Cleland, and M. L. Cohen: Solid State Commun., 52, 645 (1984).

27) W.D. Knight, W.A. de Heer, and K. Clemenger : Solid State Commun., 53, 445 (1985).

28) 石井 靖: 日本物理学会誌, 41, 467 (1986).

29) Y. Ishii, S. Ohnishi, and S. Sugano: Phys. Rev. B33, 5271 (1986).

30) W.D. Knight, K. Clemenger, W.A. de Heer, and W.A. Saunders: Phys. Rev., B31, 2539 (1985).

31) W.D. Knight, R. Monot, E. R. Dietz, and A. R. George: Phys. Rev. Lett., 40, 1324 (1978).

32) W. D. Knight: Surface Science, 106, 172 (1981).

33) T. G. Dietz, M. A. Duncan, D. E. Powers, and R. E. Smalley: J. Chem. Phys., 74, 6511 (1981).

34) V.E. Bondybey and J.H. English: J. Chem. Phys., 74, 6978 (1981).

35) D. E. Powers, S. G. Hansen, M. E. Geusic, A.C. Puiu, J. B. Hopkins, T. G. Dietz, M. A. Duncan, P. R. R. Langridge-Smith, and R. E. Smalley: J. Phys. Chem., 86, 2556 (1982).

36) A.W. Ehler: J. Appl. Phys., 37, 4962 (1966).

37) A.W. Ehler and G. L. Weissler: Appl. Phys. Lett., 8, 89 (1966).

38) P. Dhez, P. Jaegle, S. Leach, and M. Velghe: J. Appl. Phy., 40, 2545 (1969).

39) M. E. Geusic, M. D. Morse, S. C. O'Brien, and R.E. Smalley: Rev. Sci. Instrum., 56, 2123 (1985).

40) E. A. Rohlfing, D. M. Cox, and A. Kaldor: Chem. Phys. Lett., 99, 161 (1983).

41) E. A. Rohlfing, D. M. Cox, A. Kaldor, and K. H. Johnson: J. Chem. Phys., 81, 3846 (1984).

42) Y. Ishii and S. Sugano: J. Phys. Soc. Japan, 53, 3895 (1984).

43) S. C. Richtsmeier, E. K. Parks, K. Liu, L. G. Pobo, and S. J. Riley: J. Chem. Phys., 82, 3659 (1985).

44) R. L. Whetten, D. M. Cox, D. J. Trevor, and A. Kaldor: Phys. Rev. Lett., 54, 1494 (1985).

45) K. Liu, E. K. Parks, S. C. Richtsmeier, L. G. Pobo, and S. J. Riley: J. Chem. Phys., 83, 2882 (1985).

46) E. K. Parks, K. Liu, S.C. Richtsmeier, L. G. Pobo, and S. J. Riley: J. Chem. Phys., 82, 5470
(1985).

47) M. E. Geusic, M. D. Morse, and R. E. Smalley: J. Chem. Phys., 82, 590 (1985).

48) M. D. Morse, M. E. Geusic, J. R. Heath, and R. E. Smalley: J. Chem. Phys., 83, 2293 (1985).

49) P. J. Brucat, L.S. Zheng, C. L. Pettiette, S. Yang, and R. E. Smalley: J. Chem. Phys., 84, 3078 (1986).

50) D. M. Cox, D. J. Trevor, R. L. Whetten, E. A. Rohlfing, and A. Kaldor: Phys. Rev. Lett., 54, 1494 (1985).

51) K. Lee, J. Callaway, and S. Dhar: Phys. Rev., B30, 1724 (1984).

52) K. Lee, J. Callaway, K. Kwong, R. Tang, and A. Ziegler: Phys. Rev., B31, 1796 (1985).

53) C.Y. Yang, K.H. Johnson, D. R. Salahub, J. Kaspar, and R. P. Messmer: Phys. Rev., B24, 5673 (1981).

54) J. Mühlbach, K. Sattler, P. Pfau, and E. Recknagel: Surface Sci., 106, 188 (1981).

55) J. Mühlbach, K. Sattler, P. Pfau, and E. Recknagel: Phys. Lett., 87A, 415 (1982).

56) B. G. DeBoer and G.D. Stein: Surfrce Sci., 106, 84 (1981).

57) L. A. Bloomfield, R. R. Freeman, and W. L. Brown: Phys. Rev. Lett., 54, 2246 (1985).

58) J. C. Phillips: J. Chem. Phys., 83, 3330 (1985).

59) K. Raghavachari and V. Logovinsky: Phys. Rev. Lett., 55, 2853 (1985).

60) D. Tománek and M. A. Schlüter: Phys. Rev. Lett., 56, 1055 (1986).

61) J. R. Heath, Y. Liu, S.C. O'Brien, Q. Zhang, R. F. Curl, F. K. Tittel, and R. E. Smalley: J. Chem. Phys., 83, 5520 (1985).

62) A. Kasuya and Y. Nishina: Phys. Rev. Lett., 57, 755 (1986).

63) L. Brus: J. Phys. Chem., 90, 255 (1986).

64) E. A. Rohlfing, D. M. Cox, and A. Kaldor: J. Chem. Phys., 81, 3322 (1984).

65) H.W. Kroto, J. R. Heath, S. C. O'Brien, R. F. Curl, and R. E. Smalley: Nature, 318, 162 (1985).

66) L. A. Bloomfield, M. E. Geusic, R. R. Freeman, and W. L. Brown: Chem. Phys. Lett., 121, 33 (1986).

67) R. L. Disch and J. M. Schulman: Chem. Phys. Lett., 125, 465 (1986).

68) Q. L. Zhang, S. C. O'Brien, J. R. Heath, Y. Liu, R.F. Curl, H.W. Kroto, and R. E. Smalley: J. Phys. Chem., 90, 525 (1986).

69) Y. Liu, S. C. O’Brien, Q. L. Zhang, J. R. Heath, F. K. Tittel, R. F. Curl, H.W. Kroto, and R. E. Smalley: Chem. Phys. Lett., 126, 215 (1986).

70) J. R. Heath, S. C. O'Brien, Q. L. Zhang, Y. Liu, R. F. Curl, H.W. Kroto, F.K. Tittel, and R. E. Smalley: J. Am. Chem. Soc., 107, 7779 (1985).

71) M. Cox, D. J. Trevor, K. C. Reichmann, and 
A. Kaldor: J. Am. Chem. Soc., 108, 2457 (1986).

72) A. Hoareau, B. Cabaud, and R. Uzan: J. Physique, 39, 1303 (1978).

73) G. P. Schwartz, V.E. Bondybey, J. H. English, and G. J. Guattieri: Appl. Phys. Lett., 42, 952 (1983).

74) D. L. Michalopoulos, M.E. Geusic, P.R.R. Langridge-Smith, and R. E. Smalley: J. Chem. Phys., 80, 3556 (1984).

75) S. C. O'Brien, Y. Liu, Q. Zhang, J. R. Heath, F.T. Tittel, R.F. Curl, and R.E. Smalley: J. Chem. Phys., 84, 4074 (1986).

76) K. Yamanouchi, H. Watanabe, S. Koda, S. Tsuchiya, and K. Kuchitsu: Chem. Phys. Lett., 107, 290 (1984).

77) K. Yamanouchi, H. Watanabe, S. Koda, S. Tsuchiya, and K. Kuchitsu: Proc. 14th Int. Symp. Rarefied Gas Dynamics, Ed. H. Oguchi, Univ. Tokyo Press, 250 (1984).

78) K. Yamanouchi, S. Isogai, S. Tsuchiya, and K. Kuchitsu: Chem. Phys., submitted.

79) S. M. Beck, M. G. Liverman, D. L. Monts, and R. E. Smalley: J. Chem. Phys., 70, 232 (1979).

80) R. E. Smalley, L. Warton, D.H. Levy, and D. W. Chandler: J. Chem. Phys., 68, 2487 (1978).

81) C. A. Haynam and D. H. Levy: J. Phys. Chem., 87, 2091 (1983).

82) K. H. Fung, H. L. Selzle, and E.W. Schlag: Z. Naturforsch, A36, 1338 (1981).

83) C.A. Haynam, D.V. Brumbaugh, and D.H. Levy: J. Chem. Phys., 80, 2256 (1984).

84) N. Gonohe, H. Abe, N. Mikami, and M. Ito: J. Phys. Chem., 87, 4406 (1983).

85) A. Amirav, U. Even, and J. Jortner: J. Chem. Phys., 75, 2489 (1981).

86) U. Even, A. Amirav, S. Leutwyler, M. J. Ondrechen, Z. Berkovitch-Yellin, and J. Jortner: Faraday Discuss. Chem. Soc., 73: 153 (1982).

87) A. Amirav, U. Even, J. Jortner, and B. Dick: Mol. Phys., 49, 899 (1983).

88) W.E. Henke, W. Liu, H. L. Selzle, E.W. Schlag, D. Wutz, and S.H. Lin: Chem. Phys., 92, 187 (1985).

89) J. Hager and S. C. Wallace: J. Phys. Chem., 87, 2121 (1983).

90) J.C. Kettley, T.F. Palmer, J.P. Simons, and A.T. Amos: Chem. Phys. Lett., 126, 107 (1986).

91) S. Leutwyler: Chem. Phys. Lett., 107, 284 (1984).

92) S. G. Kukolich and J.F. Shea: J. Chem. Phys., 77, 5242 (1982).

93) W.L. Meerts, W.A. Majewski, and W.M. van Herpen: Can. J. Phys., 62, 1293 (1984).

94) K. Yamanouchi, S. Isogai, and S. Tsuchiya: J. Mol. Struct., 146, 349 (1986).
95) C.A. Haynam, D.V. Brumbaugh, and D. H. Levy: J. Chem. Phys., 79, 1581 (1983).

96) E. Carrasquillo, M., T.S. Zwier, and D.H. Levy: J. Chem. Phys., 83, 4990 (1985).

97) M. J. Ondrechen, Z. Berkovitch-Yellin, and J. Jortner: J. Am. Chem. Soc., 103, 6586 (1981).

98) M. Schauer, K. S. Law, and E. R. Bernstein: J. Chem. Phys., 82, 736 (1985).

99) J. Wanna and E. R. Bernstein: J. Chem. Phys., 84, 927 (1986).

100) Y. Nibu, H. Abe, N. Mikami, and M. Ito: J. Phys. Chem., 87, 3898 (1983).

101) A. Oikawa, H. Abe, N. Mikami, and M. Ito: J. Phys. Chem., 87, 83 (1983).

102) K. Fuke, T. Saito, and K. Kaya: J. Chem. Phys., 79, 2487 (1984).

103) K. Fuke, T. Saito, and K. Kaya: J. Chem. Phys., 81, 2591 (1984).

104) M.-C. Duval, C. Jouvet, and B. Soep: Chem. Phys. Lett., 119, 317 (1985).

105) K. Yamanouchi, J. Fukuyama, H. Horiguchi, S. Tsuchiya, K. Fuke, T. Saito, and K. Kaya: J. Chem. Phys., 85, 1806 (1986).

106) K. Fuke, K. Ozawa, and K. Kaya: Chem. Phys. Lett., 126, 119 (1986).

107) S. Hirayama, K. Shobatake, and K. Tabayashi : Chem. Phys. Lett., 121, 228 (1985).

108）友田真二：アイオ二クス，4月号，15 (1986).

109) Y. Ozaki, K. Murano, K. Izumi, and T. Fukuyama: J. Phys. Chem., 89, 5124 (1985).

110) (a) O. Kajimoto, K. Homma, and T. Kobayashi : J. Phys. Chem., 89, 2775 (1985).

(b) K. Homma and O. Kajimoto: J. Chem. Phys., 81, 3344 (1984).

(c) O. Kajimoto, K. Yamasaki, and K. Arita: Chem. Phys. Lett., 125, 184 (1986).

111) R. Hofmann-Sievert and A.W. Castleman, Jr.: J. Phys. Chem., 88, 3329 (1984).

112) D. Kreisle, O. Echt, M. Knapp, and E. Recknagel: Phys. Rev., A33, 768 (1986).

113) O. Echt, D. Kreisle, M. Knapp, and E. Recknagel: Chem. Phys. Lett., 108, 401 (1984).

114) O. Echt, P.D. Dao, S. Morgan, and A.W. Castleman, Jr.: J. Chem. Phys., 82, 1 (1985).

115) J. F. Garvey and R. B. Bernstein: Chem. Phys. Lett., 126, 394 (1986).

116) N. Washida: (unpublished data).

117) T. Kondow: J. Phys. Chem., (in press).

118) M. Matsuzawa: "Rydbergstates of Atoms and Molecules", eds. R.F. Stebbings and F.B. Dunning (Cambridge University Press, New York), (1983).

119) R. S. Bowles, J. J. Kolstad, J. M. Calo, and R. P. Andres: Surface Science, 106, 117 (1981).

120) U. Buck and H. Meyer: Surface Science, 156, 275 (1985). 
121) J. B. Coe, J.T. Snodgross, C. B. Friedhoff, K. M. McHugh, and K.H. Bowen: J. Chem. Phys., 83, 3169 (1985).

122) L.-S. Zheng, P. J. Brucat, C. L. Pettrette, S. Yang, and R.E. Smalley: J. Chem. Phys., 83, 4273 (1985).

123) Y. Mori and T. Kitagawa: Int. J. Mass Spectrosc. Ion Proc., 64, 169 (1985).

124) L. Wöste: Laser and Optoelekronik, 1, 9 (1983).

125) H. Shinohara, N. Nishi, and N. Washida,: J. Chem. Phys., 84, 5561 (1986).
126) L. Wöste: Int. Sym. Phys. Chem. Small Clusters, Richmond, Va. (1986).

127) G. Delacrétaz and L. Wöste: Surface Sci., 156, 770 (1985).

128) J. S. Hayden, R. Woodward, and J. L. Gole: J. Phys. Chem., 90, 1799 (1986).

129) M. D. Morse, J. B. Hopkins, P. R. R. LangridgeSmith, and R.E. Smalley: J. Chem. Phys., 79, 5316 (1983).

130) E. A. Rohlfing and J. J. Valentini : Chem. Phys. Lett., 126, 113 (1986). 